\section{Root Zone Temperatures of Viburnum odoratissimum Grown in the Multipot Box System and Conventional Systems: Measurement and Analyses of Temperature Profiles and Predicting Root Zone Temperatures}

\author{
Suat Irmak ${ }^{1}$ \\ Department of Biological Systems Engineering, University of Nebraska-Lincoln, \\ 234 L.W. Chase Hall, P.O. Box 830726, Lincoln, NE 68583-0726

\section{D.Z. Haman ${ }^{2}$} \\ Department of Agricultural and Biological Engineering, University of Florida, \\ P.O. Box 110570, Gainesville, FL 32611
}

\section{A. Irmak ${ }^{3}$}

Department of Biological Systems Engineering, Universityof Nebraska-Lincoln, 351 L.W. Chase Hall, P.O. Box 830726, Lincoln, NE 68583-0726

\section{J.W. Jones, ${ }^{4}$ B. Tonkinson, ${ }^{5}$ and D. Burch ${ }^{5}$ \\ Department of Agricultural and Biological Engineering, University of Florida, P.O. Box 110570, Gainesville, FL 32611}

T.H. Yeager ${ }^{2}$ and C. Larsen ${ }^{6}$

Environmental Horticulture Department, University of Florida, Fifield Hall, P.O. Box 110670, Gainesville, FL 32611-0670

Additional index words. MPBS, ornamental nurseries, container plants, predictions

Abstract. This research study evaluates the effectiveness of a recently introduced irrigation-plant production system, multipot box system (MPBS), for moderating root zone temperature (RZT) compared with the conventional nursery containers. The study also deals with the development, calibration, and validation of a series of models that can be used to predict maximum (max) and minimum (min) RZTs using commonly available input variables. The Viburnum odoratissimum (Ker.-gawl.) was used as the test plant. Models were calibrated in the fall growing season and validated during the summer. The RZT was used as the dependent variable while the max and min air temperatures $\left(T_{\max }\right.$ and $\left.T_{\min }\right)$ and/or incoming solar radiation $\left(R_{s}\right)$ were used as independent variables. The color of the MPBS had an effect on plant growth. Plants grown in the white MPBS had higher growth indices, shoot and root dry weights, and number of stems as compared with the plants in the black MPBS or the conventional (control) system (CS). White MPBS maintained cooler RZTs than the max air temperature during both seasons. Also, white MPBS maintained cooler RZTs than the black MPBS and CS during the two seasons. In both seasons, water temperature in the black MPBS was higher than the temperature in the white MPBS contributing to the high RZTs in the black MPBS. The RZT of the black MPBS and CS exceeded the critical value $\left(40^{\circ} \mathrm{C}\right)$, which is cited in the literatures as negatively impacting root growth, water and nutrient uptake, leaf area, plant survival, root and shoot dry weights, water status, and photosynthesis. The RZT in the CS was above $45^{\circ} \mathrm{C}$ for most of the summer season and plants were exposed to this extreme temperature for a few hours a day during most of the summer. The white MPBS provided a better environment and enhanced plant growth. For regions where ambient air temperature ranged from 2 to 41 ${ }^{\circ} \mathrm{C}$, the white MPBS can provide adequate and effective RZT protection for plants grown in No. 1, 3.8-L standard black conventional containers. Predicted RZT values were well correlated with measured values in all systems. $R_{\mathrm{s}}$ did not have an effect on predicting RZT $_{\text {max }}$ in the MPBS treatments. Wind speed did not contribute to predicting RZT in any production systems. The root mean square error between measured and predicted RZT was relatively low ranging from 0.9 to $2.8^{\circ} \mathrm{C}$. Models were able to explain at least $74 \%$ of the variability in RZTs using only $T_{m}, T_{\text {min }}$, and/or $R_{s}$. Models developed in this study should be applicable for estimating RZTs when similar management and cultural practices are present. Models of this study are practical, simple, and applicable to predict RZTs where ambient air temperature ranges from 1.9 to $40^{\circ} \mathrm{C}$. Model results should not be extrapolated beyond these limits.
Container-grown nursery plants have important production, marketing, and establishment advantages compared to field production. Root zone temperature (RZT) is a critical environmental variable that has a distinct effect on container-grown plant production. In the ornamental industry, black plastic polyethylene containers have been used for growing the majority of nursery plants. In conventional nursery containers, RZT will often exhibit significant fluctuations and impose stress on plants unless the containers are insulated or other precautions are taken. The exposure of root systems to extreme (high and low) temperatures during the growing seasons negatively affects root distribution and plant growth (Ruter, 1993). Although the temperature at which root death and/or injury occur varies with the plant species, RZT $>40^{\circ} \mathrm{C}$ for 5 to $6 \mathrm{~h} \cdot \mathrm{d}^{-1}$ has been reported to cause root death and/or injury for many container-grown plants (Ingram, 1981; Ingram and Ramcharan, 1988; Johnson and Ingram, 1984; Martin, 1990; Martin and Ingram, 1992; Martin et al., 1989). Root zone temperatures above $40^{\circ} \mathrm{C}$ have been reported to influence root growth (Johnson and Ingram, 1984), leaf area (Graves et al., 1989), plant survival (Martin et al., 1991), root and shoot dry weights (Yeager et al., 1991), water status (Graves et al., 1989), and photosynthesis (Ruter and Ingram, 1992). Root zone temperatures below $40^{\circ} \mathrm{C}$ have been reported to be optimal for plant growth (Ingram et al., 1986, 1989; Levitt, 1980; Martin and Ingram, 1992; Wong et al., 1971; Martin et al., 1989, 1991; Ruter and Ingram, 1990). However, in black plastic containers, extreme temperatures higher than the suggested optimum value are often reported. In Florida, RZT as high as $58^{\circ} \mathrm{C}$ have been reported (Martin and Ingram, 1988). Ingram (1981) reported that RZTs in black plastic containers can reach $45^{\circ} \mathrm{C}$ for several hours per day during summer months causing root injury. Daily maximum temperatures $>50$ ${ }^{\circ} \mathrm{C}$ have been reported in the substrate at the east and west container (black polyethylene) walls (Martin and Ingram, 1988). Fretz (1971) and Young and Hammett (1980) observed maximum temperatures of 49.5 and $50.8^{\circ} \mathrm{C}$, respectively, in black polyethylene containers during the summer.

Several management practices and specially designed plant production systems have been developed to improve and/or moderate RZTs. Parkerson (1990) developed an inground pot-in-pot (IGPIP) system where a

Received for publication 2 Oct. 2004.Accepted for publication 20 Nov. 2004. A contribution of the University of Nebraska-Lincoln, Agricultural Research Division journal series 14851. The mention of trade names or commercial products is solely for the information of the reader and does not constitute an endorsement or recommendation for use by the University of NebraskaLincoln or the University of Florida.

${ }^{1}$ Assistant professor. To whom reprint requests should be addressed; e-mailsirmak2@unl.edu.

${ }^{2}$ Professor.

${ }^{3}$ Assistant professor.

${ }^{4}$ Distinguished professor.

${ }^{5}$ Senior engineering technician.

${ }^{6}$ Senior biologist. 
holder pot is permanently placed in the ground with the upper rim remaining above grade. The container-grown plant is then placed inside the holder pot for the growing season (Ruter, 1993). Studies showed that the IGPIP system insulates roots from high and low temperature extremes (Schluckebier and Martin, 1997; Young and Bachman, 1996). A production system called above-ground pot-in-pot (AGPIP) was introduced (The Lerio Corp. and Nursery Supplies, Inc.) by London et al. (1998). Fretz (1971) studied temperature distributions in the nursery containers and reported that white, silver, and yellow exterior colors reduced substrate temperatures when compared to darker colored metal containers. Ingram (1981) suggested that 6-L white poly bags can be used as an alternative to conventional black rigid containers for three ornamental plant species to improve plant growth response and control the range and distribution of RZTs. Young et al. (1987) compared white copolymer and clear-poly plastics, single and double wall, on hoop houses for cold protection of ornamental plants in South Carolina. They reported that white copolymer more effectively protected against freezing. Double-layered coverings resulted in higher soil and canopy temperatures compared to single-layered coverings.

\section{Predicting Root Zone Temperatures}

Although RZT is an important variable in container-grown ornamental plant production, direct measurement of the temperature may not always be possible. With the exception of a few studies, little attention has been given to developing and using models to predict RZT of container-grown plants. Simulation models allow researchers to study the response of RZT to ambient air temperatures and other variables such as solubility of nutrients and their interactions with the plant root and substrate without conducting time consuming, difficult, and expensive field studies. Models also allow researchers to develop and evaluate best management practices to enhance nursery operation.

Martin and Ingram (1992) developed a three dimensional model using an energy balance approach to numerically simulate the thermal environment of a polyethylene container-root system in 10-L containers in Gainesville, Fla. They studied the effect of net radiation, convection, evaporation, and conduction on thermal energy exchanges at the top surfaces of the substrate. The effect of volumetric water content on substrate temperature patterns for different substrates was also studied. In their study, thermal energy exchanges at the system's boundaries were a function of solar radiation, convection, evaporation, and conduction energy fluxes. Conduction and evaporation had little effect on thermal energy flows across the substrate surface. Their model required thermal conductivity, bulk density and specific heat capacity of the substrate, solar radiation, wind speed, relative humidity, and maximum and minimum air temperature as input variables. Model validation results were in a good agreement with temperatures measured at the exterior walls of the container $(0.02 \mathrm{~m}$ inside the container wall at north, south, east, and west sides) and the root medium ( $0.02 \mathrm{~m}$ above the container bottom, in the center of the container, and $0.02 \mathrm{~m}$ below the substrate surface). They reported that the thermal diffusivity of the substrate increased as volumetric water content increased. They suggested that irrigation applied in the afternoon would help moderate high temperatures in pine bark substrate.

Martin and Ingram (1993) used the model developed by Martin and Ingram (1992) to simulate the effect of container volume and shape on summer temperature patterns for black polyethylene nursery containers filled with a pine bark in Phoenix, Ariz., and Lexington, Ky. They found that, for both locations, predicted temperature patterns in rooting medium adjacent to the container wall decreased as the wall tilt angle increased. Predicted temperature patterns at the center of the container profile were lower with increased container height and wall tilt angle. As the container volume decreased, the temperature at the center of the substrate increased. Based on the simulation results, they suggested that large containers with walls tilted outward may be practical for container nursery production in hot climates.

Using sophisticated empirical equations for RZT estimations can be difficult for growers, consultants, extension personnel, and technicians who may not be familiar working with complex equations. In addition, variables such as thermal conductivity, bulk density and specific heat capacity of the substrate may not be readily available to solve the energy balance equations for RZT predictions. The simplicity of the use and interpretation of the RZT prediction models can also encourage growers and their advisors to monitor their own RZT data to use them in different applications. Thus, there is a need for developing models that can be used to predict RZT profiles from easily obtainable inputs with a minimum of computations.

Recently, a new irrigation and plant production system-the multipot box system (MPBS) - has been introduced (Haman et al., 1998; Irmak, 2002; Irmak et al., 2001, 2003, 2004) for increased water application efficiency and crop water use efficiency and water conservation for container-grown ornamentals. Irmak et al. (2003, 2004) investigated the growth of $V$. odoratissimum grown in the black and white MPBS, and conventional (control) system (CS). White and black MPBSs were very effective in increasing irrigation water use efficiencies, rainfall harvesting, and plant biomass production as compared with the CS. The color of the MPBS had an effect on plant growth and no affect on irrigation demand or runoff. The seasonal irrigation water use efficiency was greater for plants grown in the white MPBS than plants in the black MPBS and CS. The white MPBS produced higher plant biomass (stem and root dry matter), growth indices, and growth rates compared with the black MPBS and CS in the summer and fall. They observed that the plants in the white MPBS were exposed to less plant stress, had higher plant water potential values, and lower stomatal resistances to the water vapor transport during both seasons. They attributed the growth differences to temperature stress induced by high RZT. However, quantifying and analyzing RZT profiles in the MPBS and CS treatments have not been studied. Assessment of which system moderates extreme temperatures and provides a better environment for plant growth would help producers select which color of MPBS to use for climatic conditions similar to those in this study.

The main objectives of the study were 1) to quantify and analyze seasonal and diurnal patterns of multiple-depths of RZTs in the containers and water temperatures in the reservoirs of the MPBSs for $V$. odoratissimum grown in the black and white MPBS and CS, and 2) to develop and validate a series of models for predicting $\mathrm{RZT}_{\text {max }}$ and $\mathrm{RZT}_{\text {min }}$ for $V$. odoratissimum grown under north-central Florida conditions using commonly available inputs and a minimum of computations.

\section{Materials and Methods}

\section{MPBS description}

The MPBS consisted of two sections (lower and upper) made of fiberglass and painted black or white for UV protection (Fig. 1A and B). The surface area of the system is $0.787 \mathrm{~m}^{2}(0.82 \times$ $0.96 \mathrm{~m})$. These dimensions were selected so that the boxes could be placed end to end in beds to form a continuous surface with walkways interspersed for plant maintenance in a normal nursery operation. The lower section (reservoir) had four longitudinal channels (about $0.106 \mathrm{~m}$ high) that formed water reservoirs with three ridges, sized so that the box can be moved by placing forklift tongues under the outer ridges. Each ridge surface was covered with polyester fabric (Knowlton Nonwovens East, Troy, N.H.) to serve as the wicking material (capillary mat). This material is used to draw water upward by capillary action. Thus, water in the substrate was replaced by capillarity as needed. The upper section of the MPBS supported the containers and minimized evaporation losses from the reservoir. The surface of the upper section was concave around each container opening to capture rain and irrigation water. The lower section (reservoir) stores the captured water until used by plants. Each box holds nine plastic standard containers (C-650; The Lerio Corporation, El Campo, Texas) with a volume, height, and diameter of $3.8 \mathrm{~L}, 0.17$ $\mathrm{m}$, and $0.15 \mathrm{~m}$, respectively. The same type of containers was used in the MPBS and CS. The only difference is that the containers placed in the MPBS were modified by drilling four equally spaced holes $(0.013 \mathrm{~m}$ in diameter $)$ through the bottom of the containers to enable the substrate to be in a good contact with the wicking material for adequate water absorption. Then, the containers were set directly on the ridges in the MPBS.

A drip-irrigation system was installed to irrigate the boxes. Each channel in the reservoir was equipped with a pressure-compensating drip irrigation emitter (Chapin Watermatics Inc., Watertown, N.Y.). Emitters with a 7.6$\mathrm{L} \cdot \mathrm{h}^{-1}$ flow rate were installed directly on the 

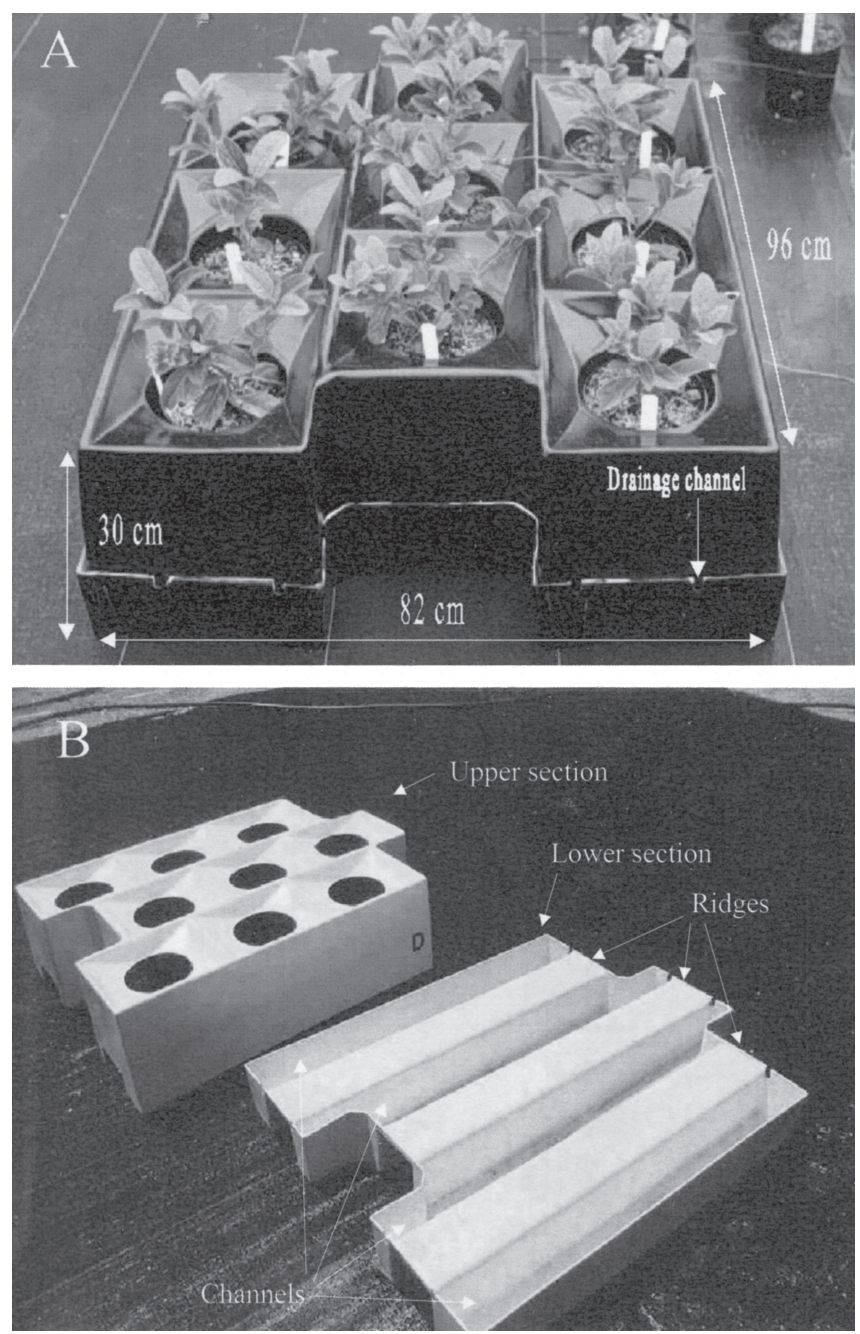

Fig. 1. Original design of the black MPBS containing nine standard plastic containers (A) and some components of a white MPBS placed on a black polyethylene groundcover (B).

mainline and water was delivered to the box using a spaghetti tube and a lead weight placed in each channel. Each box was equipped with a side-mount level switch (model LS-7; State Instruments, Inc., Tampa, Fla.) to trigger irrigations automatically. The level switches were installed at $0.01,0.02$, and $0.03 \mathrm{~m}$ from the bottom of the reservoir (depending on the treatment) and triggered irrigations when the water level in the reservoir dropped to predetermined levels.

\section{Description of the CS (control treatment)}

The CS served as the control treatment and represented the irrigation system commonly used by most nursery growers. Standard containers in the CS were spaced in three rows 0.30 $\mathrm{m}$ apart (between rows and within rows) and set directly on separate black polypropylene ground sheeting. The reason of setting the CS containers on separate ground sheeting was that this treatment was irrigated using overhead sprinklers which is a common practice used by many producers in the southeastern U.S.

\section{Field experiments}

General experimental procedures. Field experiments were conducted outdoors on the campus of the University of Florida at
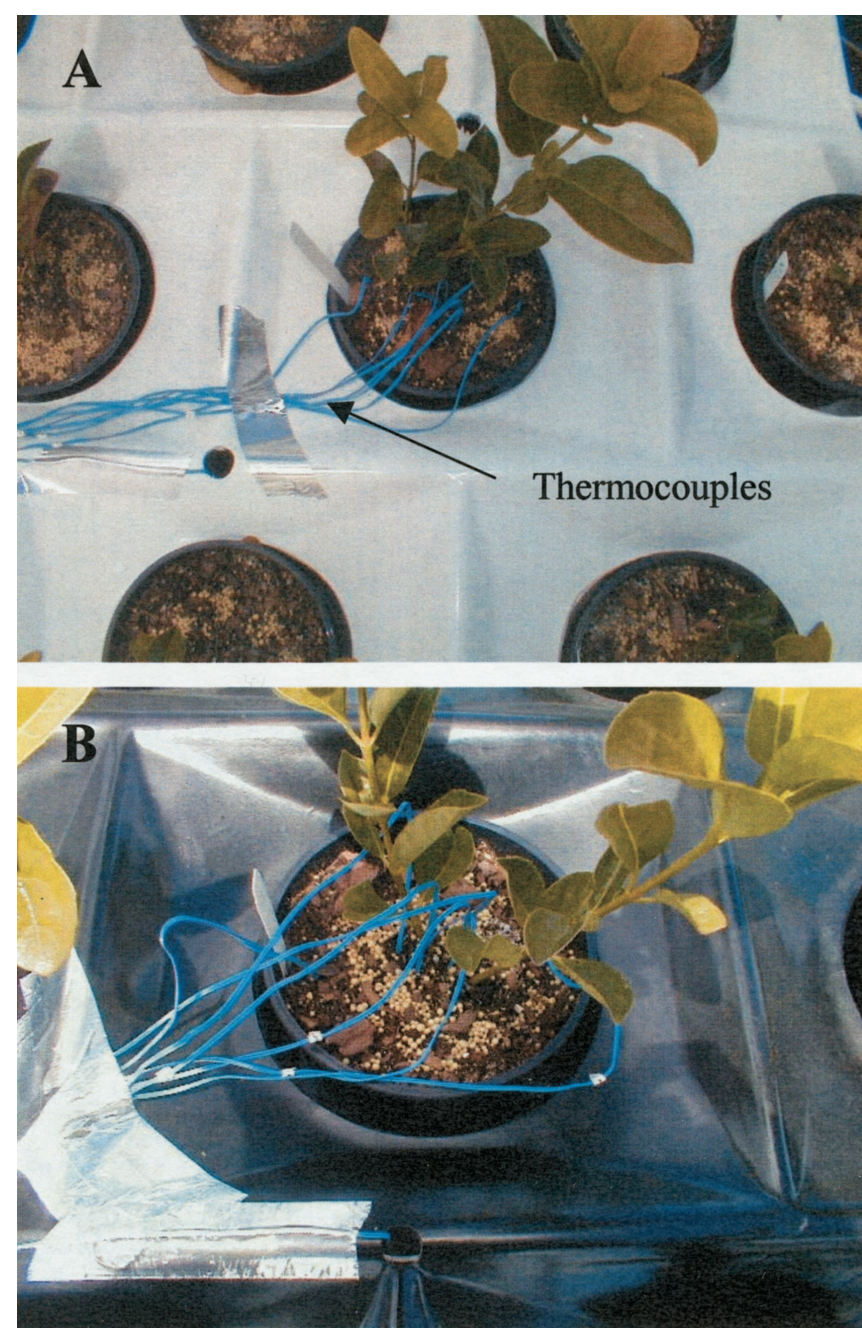

Fig. 2. Thermocouples placed in the center containers to measure RZT at the multiple depths $(0.03,0.06,0.09,0.12$, and $0.15 \mathrm{~m}$ from the surface of the container).
Gainesville (latitude $29^{\circ} 38^{\prime}$, longitude $82^{\circ} 22^{\prime}$, elevation $29.3 \mathrm{~m}$ ) in the summer and fall of 2001. Unless noted otherwise, the experimental procedures were the same for the two growing seasons. Viburnum odoratissimum, Ker.-Gawl. (sweet viburnum, Adoxaceae) was grown as a test plant. This plant is being grown extensively as a nursery plant throughout Florida. Seven treatments were imposed: 1 ) white MPBS with level switches installed at $0.01,0.02$, and 0.03 $\mathrm{m}(\mathrm{W} 1, \mathrm{~W} 2$, and $\mathrm{W} 3)$ from the bottom of the reservoir, 2) black MPBS with level switches installed at $0.01,0.02$, and $0.03 \mathrm{~m}(\mathrm{~B} 1, \mathrm{~B} 2$, and B3), and 3) The CS. There were nine plants in each replication. Treatments (boxes) were replicated using randomized complete block design. Containers were filled with a substrate mix containing pine bark, Canadian peat, and sand (2:1:1, by volume) mix, amended with $4.2 \mathrm{~kg} \cdot \mathrm{m}^{-3}$ of dolomitic James River Limestone and $0.9 \mathrm{~kg} \cdot \mathrm{m}^{-3}$ of Micromax (The Scotts Co., Marysville, Ohio) and placed in each MPBS. The same substrate was used for the containers in the CS. Healthy and uniform size plants were transplanted into the substrate-filled containers and grown 3 to 4 weeks in a shadehouse (30\% shade) and were hand-watered as needed. Plants were top dressed with 0.014 $\mathrm{kg} /$ container of Osmocote $18 \mathrm{~N}-2.6 \mathrm{P}-9.7 \mathrm{~K}$
(18-6-12) controlled (slow-release) fertilizer (The Scotts Co.) at the beginning of each experiment. Experiment starting and termination dates for the summer and fall seasons were 17 May to 9 Aug. and 28 Aug. to 21 Dec. 2001, respectively.

The growth index of plants was based on plant height measured from the substrate surface to the tip of the tallest leaf on selected dates. On the same day, plant widths were measured in both east-west and north-south directions. In both seasons, six growth measurements were taken from the plants grown in the white and black MPBSs. Eleven and nine growth measurements were taken from the CS treatment in the summer and fall, respectively. All plants were measured in all replications, thus, 189 plants were measured for each sampling date. Growth indices (GIs) were calculated as

$\mathrm{GI}=\mathrm{H}+[(\mathrm{WEW}+\mathrm{WNS}) / 2] / 2$

where, $\mathrm{H}$ is the plant height $(\mathrm{m}), \mathrm{WEW}$ is the canopy width in east-west direction $(\mathrm{m})$, and WNS is the canopy width in north-south direction $(\mathrm{m})$. Experiments were terminated when the plants in the MPBS treatments reached approximately a marketable size. A GI value of 40 was assumed to represent marketable size (Florida Dept. of Agriculture and Consumer 
Table 1. Statistical analyses of the growth index (GI) at harvest, number of stems, and shoot and root dry weights in summer and fall growing seasons [W3, W2, and $\mathrm{W} 1$ = white multipot box system (MPBS) with level switch installed at 0.01, 0.02, and $0.03 \mathrm{~m}$ from the bottom of the reservoir, respectively; B3, B2, and $\mathrm{B} 1$ = black MPBS with level switch installed at $0.01,0.02$, and $0.03 \mathrm{~m}$ from the bottom of the reservoir; and CS = conventional system].

\begin{tabular}{|c|c|c|c|c|c|c|c|c|}
\hline \multirow[b]{2}{*}{ Treatment } & \multicolumn{4}{|c|}{ Summer growing season } & \multicolumn{4}{|c|}{ Fall growing season } \\
\hline & $\begin{array}{c}\text { GI at } \\
\text { harvest }^{z, y}\end{array}$ & $\begin{array}{l}\text { No. of stems } \\
\text { in each plant }{ }^{z, y}\end{array}$ & $\begin{array}{l}\text { Stem dry } \\
\text { wt }(g)^{z, y}\end{array}$ & $\begin{array}{l}\text { Root dry } \\
\text { wt (g) }\end{array}$ & $\begin{array}{c}\text { GI at } \\
\text { harvest }^{z}\end{array}$ & $\begin{array}{l}\text { No. of stems } \\
\text { in each plant }\end{array}$ & $\begin{array}{l}\text { Stem dry } \\
\text { wt }(g)^{z, y}\end{array}$ & $\begin{array}{l}\text { Root dry } \\
\text { wt }(g)^{z, y}\end{array}$ \\
\hline W3 & $50.4(4.0) \mathrm{a}^{\mathrm{x}}$ & $10.1(1.7) \mathrm{a}$ & $46.4(8.3) \mathrm{a}$ & $12.9(2.5) \mathrm{a}$ & $43.0(3.1) \mathrm{a}$ & $8.3(1.6) \mathrm{a}$ & $41.0(7.7) \mathrm{a}$ & $19.8(3.0) \mathrm{a}$ \\
\hline W2 & $49.2(3.8) \mathrm{a}$ & $9.6(1.6) \mathrm{a}$ & $46.3(8.0) \mathrm{a}$ & 12.9 (2.9)a & $42.5(5.4) \mathrm{a}$ & $8.3(1.4) \mathrm{a}$ & $38.6(7.0) \mathrm{a}$ & $18.8(2.8) \mathrm{a}$ \\
\hline W1 & 48.4 (4.6)a & $9.4(1.8) \mathrm{a}$ & $44.4(8.2) \mathrm{a}$ & $11.5(3.0) \mathrm{a}$ & $42.6(4.1) \mathrm{a}$ & $7.9(1.3) \mathrm{a}$ & $39.1(7.1) a$ & $19.0(2.9) \mathrm{a}$ \\
\hline B3 & $43.1(4.6) b$ & $4.4(2.0) b$ & $32.7(7.5) b$ & $8.90(1.9) \mathrm{b}$ & $40.5(7.2) b$ & $7.4(1.4) \mathrm{a}$ & $32.4(6.8) b$ & $13.5(2.6) \mathrm{b}$ \\
\hline B2 & $40.0(4.5) \mathrm{b}$ & $4.3(1.9) \mathrm{b}$ & $30.9(7.5) b$ & $8.20(1.6) \mathrm{b}$ & $41.1(4.0) \mathrm{b}$ & $7.4(1.4) \mathrm{a}$ & $34.3(7.2) \mathrm{b}$ & $13.4(2.2) \mathrm{b}$ \\
\hline B1 & $41.7(4.7) b$ & $4.4(1.4) b$ & $31.9(6.9) \mathrm{b}$ & $9.10(1.9) \mathrm{b}$ & $40.8(5.7) \mathrm{b}$ & $7.5(1.2) \mathrm{a}$ & $32.3(6.8) b$ & $12.9(1.9) \mathrm{b}$ \\
\hline $\mathrm{CS}^{\mathrm{w}}$ & $33.2(3.7) \mathrm{c}$ & $2.4(0.6) \mathrm{c}$ & $17.7(5.5) \mathrm{c}$ & $4.30(1.6) \mathrm{c}$ & $30.8(4.3) \mathrm{c}$ & $5.0(1.2) \mathrm{b}$ & $21.0(5.1) \mathrm{c}$ & $10.1(2.2) \mathrm{c}$ \\
\hline
\end{tabular}

${ }^{\mathrm{z}}$ Average of 27 plants from three replications (nine plants in each replication).

Values in parenthesis indicate standard deviations (SD).

'Means followed by different letters among the treatments are different $(P<0.05)$ as indicated by Duncan's multiple range test.

wDry weights, GI, and number of stems of the plants in the CS harvested when the plants grown in the MPBS reached marketable size.

Services, 1997). At termination, shoots of all plants were severed above the uppermost roots, the roots were cleaned from the substrate, and shoot and root dry weights were measured after drying to a constant weight at $70^{\circ} \mathrm{C}$. The number of stems on each plant was counted at harvest.

Irrigation applications. The irrigated area of the CS was $6.0 \times 6.0 \mathrm{~m}$. The CS plot was irrigated with four rotary drive sprinkler heads (PGM-04-A; Hunter Industries, San Marcos, Calif.) mounted on 1.3-m risers and located at the corners of the plot. Water was applied daily for $1 \mathrm{~h}$ with an irrigation application rate of $18 \mathrm{~mm} \cdot \mathrm{h}^{-1}$. Irrigations were applied to the MPBSs whenever the reservoir in the bottom of the boxes receded to $0.025,0.035$, and 0.045 $\mathrm{m}$, depending on the treatment. Irrigation was applied for $30 \mathrm{~min}$ to deliver about $16 \mathrm{~L} \mathrm{(20}$ $\mathrm{mm}$ ) of water. The main purpose of not irrigating the boxes to the full reservoir capacity $(0.106 \mathrm{~m})$ was to keep a part of the reservoir empty to provide storage for the rainwater. A rain sensor was installed to both the MPBS and CS plots to shut off irrigations when about 12 $\mathrm{mm}$ of rain occurred.

Rootzone and water temperature measurements. The RZT measurements were made every $10 \mathrm{~min}$ and averaged on hourly basis throughout the two growing seasons. Measurements were taken from 23 May to 9 Aug. in the summer and from $29 \mathrm{Aug}$. to $20 \mathrm{Dec}$. in the fall. The center container in three replications in the white and black MPBSs (W2 and B2, respectively), and CS treatments were equipped with thermocouples for RZT measurements (Fig. 2A and B). Copper-constantan (0.0005 $\mathrm{m})$ thermocouples were placed at the depths of $0.03,0.06,0.09,0.12$, and $0.15 \mathrm{~m}$ from the surface at the center location vertically. The substrate was hand packed to assure an adequate contact with the thermocouples. Additional thermocouples were placed in the reservoirs of the white and black MPBSs to measure water temperature every $10 \mathrm{~min}$. Two thermocouples were placed in each reservoir and temperature readings were averaged. In addition, two thermocouples in the center containers of the two replications of the black and white MPBS treatments were placed at the center to measure the ambient temperature inside the MPBS. Thermocouples were connected to the data acquisition systems and measurements were recorded using a datalogger and a multiplexer (model CR-10X and model 32M; Campbell Scientific Inc., Logan, Utah). An automated weather station was set on the short green grass site about $20 \mathrm{~m}$ from the experimental site to record necessary climate variables for temperature profile analyses and model calibration and validation. The data collected at the weather station included air temperature, relative humidity, incoming solar radiation, wind speed at $2 \mathrm{~m}$, and rainfall. Growth and temperature responses to treatments were analyzed by analysis of variance (ANOVA). Duncan's multiple range test (DMRT) was used to identify which treatments differed at the $5 \%$ significance level.

\section{RZT model development}

Two models were developed to predict the maximum RZT for the white and black MPBS while only one was developed to predict the minimum RZT. Reasons for developing two models for RZT $\mathrm{T}_{\text {max }}$ and one model for $\mathrm{RZT}_{\min }$ will be discussed later. The average RZT values of all depths for either the white or the black MPBS were used in model development. The models for predicting RZT for the black and white MPBSs were calibrated individually. The calibrated models were used to predictRZT at $0.12 \mathrm{~m}$ from the surface of the container in the CS and results were compared with the measured RZT values for all cases during validation. For the CS, two models were developed to predict $\mathrm{RZT}_{\text {max }}$ and $\mathrm{RZT}_{\text {min }}$ at $0.12 \mathrm{~m}$ from the surface of the containers. During model development the plant root zone was assumed to be approximately at the $1 / 3$ of the distance from the bottom of the container. Most plant root density is assumed to be in this zone. The height of a black no. 1 standard polyethylene container is about $0.17 \mathrm{~m}$ and $1 / 3$ of this height corresponds to
$0.057 \mathrm{~m}$ from the bottom of the container or about $0.12 \mathrm{~m}$ from the surface of the container. Thus, RZT measurements made at $0.12 \mathrm{~m}$ from the surface of the container represented the critical RZT for the $V$. odoratissimum.

Unless mentioned otherwise, the same procedures were used to develop models for the white and black MPBS and CS. Multilinear regression was used to develop the coefficients

Fig. 3. Seasonal pattern of daily maximum root zone temperature in the black (A) and white (B) MPBS, and CS during the summer season.
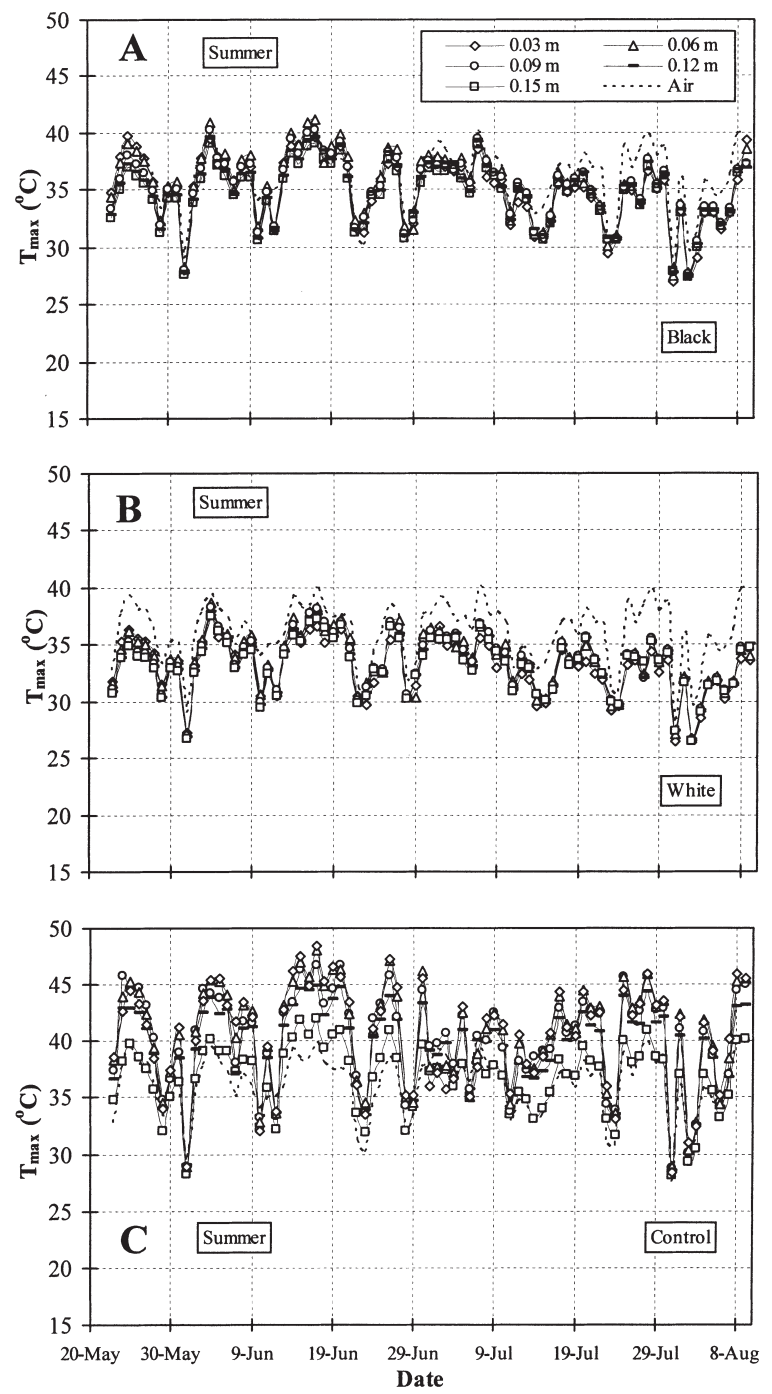
Table 2. Statistical analyses (ANOVA) of the root zone temperatures (RZTs) between the black and white multipot box system (MPBS) treatments and between the multiple depths in the conventional system (CS) for the summer and fall growing seasons. Analyses were conducted at $5 \%$ significance level.

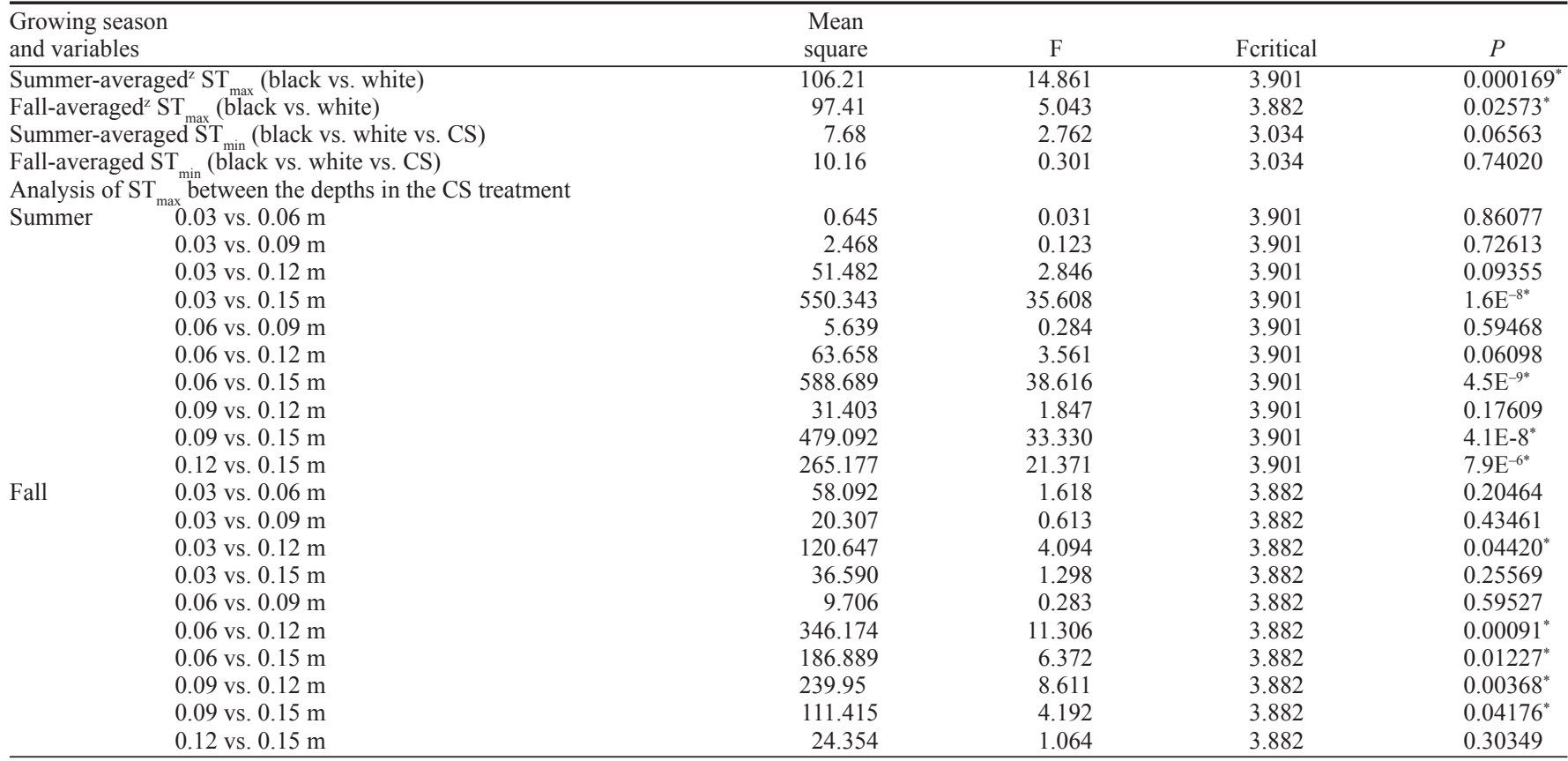

${ }^{\mathrm{z}}$ Average values of RZT in all depths in the black and white MPBS treatments.

"Significant at $5 \%$ significance level as indicated by Duncan's multiple range test.

Table 3. Maximum, minimum, and seasonal average max root zone temperatures (RZTs) in the conventional system (CS) in the summer and fall growing seasons.

\begin{tabular}{lcccc}
\hline $\begin{array}{l}\text { Growing } \\
\text { season }\end{array}$ & $\begin{array}{c}\text { Depth }^{\mathrm{z}} \\
(\mathrm{m})\end{array}$ & $\begin{array}{c}\mathrm{RZT}_{\text {max }} \\
\left({ }^{\circ} \mathrm{C}\right)\end{array}$ & $\begin{array}{c}\mathrm{RZT}_{\text {min }} \\
\left({ }^{\circ} \mathrm{C}\right)\end{array}$ & $\begin{array}{c}\text { Seasonal } \\
\text { avg }\left({ }^{\circ} \mathrm{C}\right)\end{array}$ \\
\hline Summer & $0.03 \mathrm{a}^{\mathrm{y}}$ & 48.4 & 28.3 & 40.5 \\
& $0.06 \mathrm{a}$ & 48.0 & 28.9 & 40.6 \\
& $0.09 \mathrm{a}$ & 46.8 & 28.7 & 40.2 \\
& $0.12 \mathrm{a}$ & 44.9 & 28.5 & 39.3 \\
Fall & $0.15 \mathrm{~b}$ & 42.0 & 28.1 & 36.8 \\
& $0.03 \mathrm{a}$ & 47.4 & 20.0 & 33.8 \\
& $0.06 \mathrm{ac}$ & 47.9 & 20.4 & 34.9 \\
& $0.09 \mathrm{ad}$ & 46.8 & 21.0 & 34.4 \\
& $0.12 \mathrm{~b}$ & 43.6 & 20.8 & 32.4 \\
& $0.15 \mathrm{ab}$ & 42.2 & 20.7 & 33.0 \\
\hline
\end{tabular}

${ }^{2}$ Depths followed by different letters are different in terms of RZT max $_{\text {an }}$ as indicated by Duncan's multiple range test at $5 \%$ significance level.

${ }^{y}$ Significant at $5 \%$ significance level as indicated by Duncan's multiple range test.

for the models. The measured RZT values in the fall season (29 Aug. to 20 Dec.) were used to calibrate the coefficients in the models. Then, the models were validated using the measured data from the summer growing season (23 May to 9 Aug.). In the multilinear regression analyses, measured RZT values were used as dependent variables. Depending on the treatment, the solar radiation $\left(\mathrm{R}_{\mathrm{s}}\right)$, maximum air temperature, $\left(\mathrm{T}_{\max }\right)$, and minimum air temperature $\left(\mathrm{T}_{\min }\right)$, were used as independent variables to determine the equation-specific coefficients. The general form of the multilinear equation that relates the dependent variable (RZT) to a set of quantitative independent variables $\left(R_{\mathrm{s}}\right.$, $\mathrm{T}_{\max }$, and $\mathrm{T}_{\min }$ ) was

$R Z T=\beta_{0}+\beta_{1} X_{1}+\beta_{2} X_{2}+\beta_{3} X_{3}$

where RZT is root zone temperature $\left({ }^{\circ} \mathrm{C}\right), B_{0}$ is the intercept, $\beta_{1}, \beta_{2}$, and $\beta_{3}$ represent the slope of the regression line, and $\mathrm{X} 1, \mathrm{X} 2$, and $\mathrm{X} 3$ are the independent variables. The root mean square error (RMSE), coefficient of determination $\left(r^{2}\right)$ between predicted and measured RZTs, and seasonal average ratio of predicted RZT to measured RZT were computed and used as indicators of accuracy and consistency of a given model's performance. The RMSE $\left({ }^{\circ} \mathrm{C}\right)$ values were calculated as

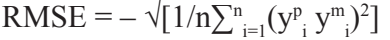

where $n$ is the number of observations, $y^{p}$ and $\mathrm{y}_{\mathrm{i}}^{\mathrm{m}}$ are predicted and measured RZT $\left({ }^{\circ} \mathrm{C}\right)$, respectively.

\section{Results and Discussion}

\section{Plant growth analyses}

Growth indices (GI), shoot and root dry weights, and the number of stems on the plants grown in the white and black MPBS and CS at harvest are given in Table 1. Plants grown in the white MPBS treatments reached marketable size $(\mathrm{GI}=40)$ earlier compared to plants in the black MPBS and CS treatments. In the summer, final GI values of the plants in all white MPBS treatments (W1, W2, and W3) were significantly greater $(P<0.05)$ than plants in the black MPBS and CS (Table 1). White MPBS plants had more stems in the summer compared to the other treatments. In the fall, the final GI values of the plants in all white MPBS treatments were also significantly greater than those in the black MPBS and CS plants. In both seasons, the white MPBS plants produced significantly higher shoot and root dry weights as compared to the other treatments.

\section{Seasonal pattern of daily maximum and minimum RZT at multiple depths}

Maximum RZT profiles during the summer. Figure 3 represents seasonal pattern of daily $\mathrm{RZT}_{\max }$ at $0.03,0.06,0.09,0.12$, and $0.15 \mathrm{~m}$ depths for the containers placed in the white and black MPBS and CS in the summer. Statistical analyses of the differences in RZTs between the white and black MPBs at different depths are given in Table 2. RZT in the black MPBS varied from $27.7^{\circ} \mathrm{C}$ on 1 June to $41.1^{\circ} \mathrm{C}$ on 17 June, whereas seasonal RZTs were usually lower for the white MPBS ranging from 26.4 ${ }^{\circ} \mathrm{C}$ on 31 July to $38.7^{\circ} \mathrm{C}$ on 4 June (Fig. 3A and B). The RZTs at multiple depths were not different $(P>0.05)$ for the black or white MPBS during the growing season. However, when these RZTs for all depths were averaged for the black and white MPBS, the average RZTs in the white MPBS were $1.6^{\circ} \mathrm{C}$ (seasonal average) cooler $(P<0.05)$ than those in the black MPBS throughout the summer (Table 2). During the period of 23 May to 14 July, the RZTs in the black MPBS showed similar trends with the max air temperature. However, the seasonal average RZTs were 2 to $3{ }^{\circ} \mathrm{C}$ warmer than the air temperature (Fig. 3A). Starting from 15 June, the RZTs in the black MPBS maintained 2 to $4{ }^{\circ} \mathrm{C}$ lower temperatures than the max air temperature for the rest of the season. In general, the white MPBS maintained 3 to $5{ }^{\circ} \mathrm{C}$ cooler temperatures than the max air temperature throughout the season (Fig. 3B) indicating that the plant roots in the containers placed in the white MPBS were better protected from the high temperatures compared to the plant roots in the black MPBS and CS.

$\mathrm{RZT}_{\text {max }}$ at multiple depths showed significant variations in CS treatment in the summer (Fig. 3C) and the magnitude of daily RZT fluctuations was greater than those in the black and white MPBS throughout the season. Statistical analysis of RZT $\mathrm{T}_{\max }$ between the depths are given in Table 2. The max, min and seasonal average RZT at five different depths and the DMRT results are reported in Table $3 . \mathrm{RZT}_{\text {max }}$ showed 

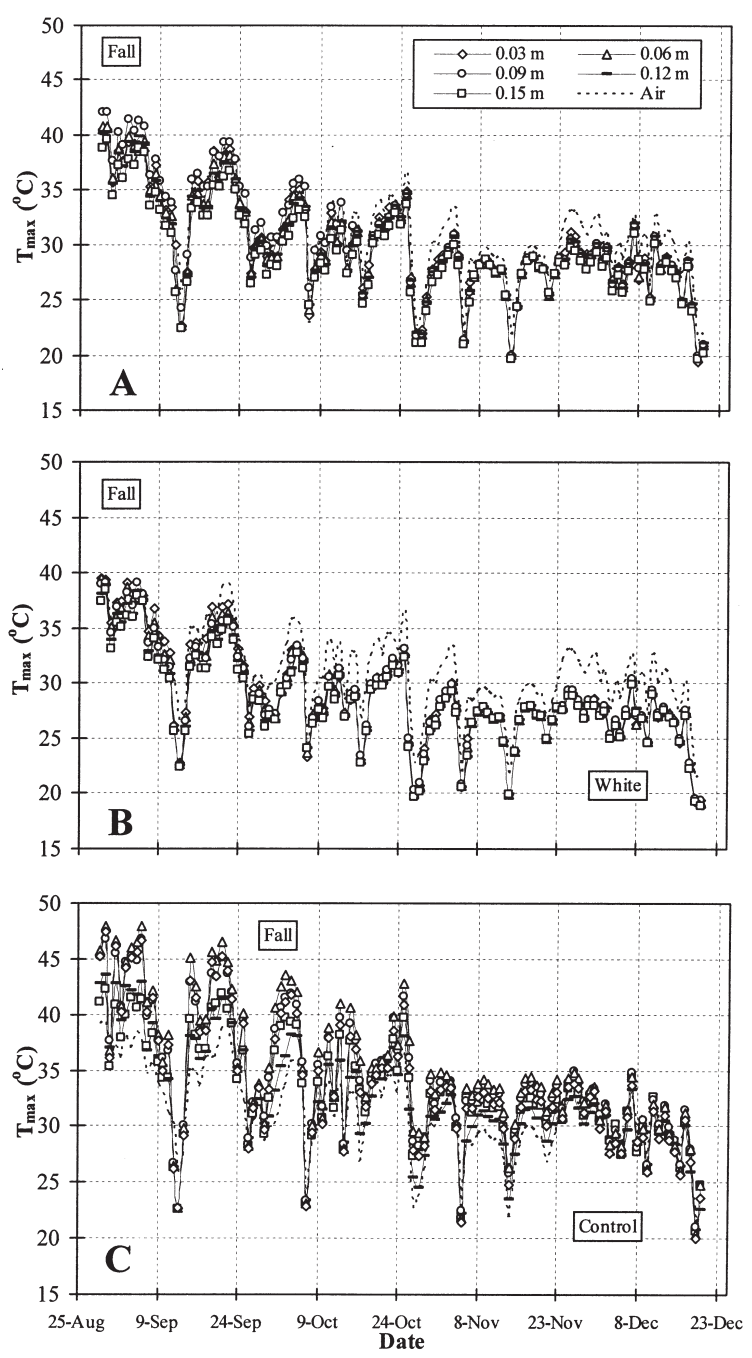

Fig. 4. Seasonal pattern of daily maximum RZT in the black (A) and white (B) MPBS, and CS during the fall season.

variations with depth. The top depth $(0.03 \mathrm{~m})$ had the warmest RZT throughout the season (Fig. 3C). Although the RZT at this depth was higher than those in all other depths, it was only significantly higher $(P<0.05)$ than the RZTs in $0.15 \mathrm{~m}$ depth (Table 3$)$. The bottom depth $(0.15 \mathrm{~m})$ maintained consistently cooler RZT than in all other depths.

Maximum RZT profiles in the fall growing season. Similar results with lower RZTs due to the lower air temperature and solar radiation were obtained in the fall. The RZT in the black MPBS (Fig. 4A) ranged from 19.7 to $42.1^{\circ} \mathrm{C}$. The difference in RZT between the depths was not significant. From 29 Aug. to 30 Oct., the RZT in all depths followed similar values as the max air temperature. Starting on 31 Oct. and continuing through the end of the season, the RZTs in all depths were 1.0 to $2.6^{\circ} \mathrm{C}$ lower than the air temperature. Early in the season (29 Aug. to 27 Sept.), RZTs in the white MPBS were similar to air temperature and starting from early October, the white MPBS maintained 1.0 to $3.6^{\circ} \mathrm{C}$ lower RZTs than the air temperature for the rest of the season (Fig. 4B). When the RZTs in all depths in each treatment (black and white MPBS) were averaged, the RZTs in the
blackMPBS were $1.3^{\circ} \mathrm{C}$ (seasonal average) warmer $(P<0.05)$ than those in the white MPBS during the fall (Table 2).

The RZTs in five depths in the CS treatment were different from those obtained in the summer growing season (Fig. 4C). Statistical analyses of the RZTs in five depths for the CS treatment are presented in Table 2. The max, min, and seasonal average RZT values and DMRT results are given in Table 3 . RZTs were lower compared to those measured in the summer for all depths. In contrast to the summer results, the RZT at $0.06 \mathrm{~m}$ was the highest in the fall (Fig. 4C), and it was only significantly higher than the RZTs in $0.12 \mathrm{~m}$ and $0.15 \mathrm{~m}$ depths (Table 2). This might indicate that a heat buildup occurred in this depth. The max, min, and seasonal average of RZT for the $0.06 \mathrm{~m}$ depth were $47.4,20.0$, and $33.8^{\circ} \mathrm{C}$, respectively, (Table $3)$. All depths showed significant reduction in temperature starting from 25 Oct. and continued until the end of the growing season due to the lower air temperature and solar radiation in this period.

Overall results of RZT patterns indicated that the RZTs in the white MPBS were cooler $(P<0.05)$ than the black MPBS and CS. The RZTs in the black MPBS and CS exceeded the critical value $\left(40{ }^{\circ} \mathrm{C}\right)$ cited in the literature as negatively impacting plant growth and root development. Root death and/or injury, depending on the plant species, often occurs when the root zone is exposed repeatedly (for 5 to $6 \mathrm{~h}$ daily) to temperatures $\geq 40{ }^{\circ} \mathrm{C}$ (Johnson and Ingram, 1984; Ingram and Ramcharan, 1988; Martin et al., 1989). The RZTs in the CS plants were above $45^{\circ} \mathrm{C}$ for most of the summer. These results suggest that the white MPBS successfully insulated the plant root zone against extremely high ambient air temperatures in all five depths during the summer providing a better environment and enhancing plant growth. Thus, plants grown in the white MPBS having higher GI, dry weights, and number of stems compared to the plants in the black MPBS and CS can be attributed to the moderated RZTs in the white MPBS.

Ambient temperature inside the MPBS. RZT $_{\text {max }}$ was higher in the CS compared to the MPBS treatments mainly due to the fact that the containers in the CS are exposed to the direct effect of the extreme ambient temperature and solar radiation. Maximum RZTs in the black MPBS being higher than those in the white MPBS is, in part, due to the higher rate of radiant energy absorption by the black color and increased ambient air temperature in the MPBS and consequently elevated RZTs. We can assume that the white MPBS reflects more radiant energy received at the surface of the box compared to the black MPBS resulting in lower radiant energy absorption and, thus, lower ambient and RZTs. In addition, the RZT is a function of the substrate moisture content. In the MPBS, the irrigation water for the plants was supplied by subirrigation from the system reservoir via the capillary mat. Thus, plants never experienced water-limiting conditions and the water content of the root zone in this system was usually higher than the other freely drained CS containers. This high water content helps to moderate the effect of the extreme ambient temperatures. Substrate moisture content in the CS containers decreases with time during the day and reaches its lowest value in the late afternoon as water evaporates from the container surface and/or depleted by the plants in the absence of rainfall contributing to the high RZT in the container.

To explore the above-mentioned hypotheses further, daily maximum ambient temperature measured in the center and half distance between the top and bottom of the black and white MPBS in the summer and fall are plotted in Fig. 5A and B. In Fig. 5A and B, the max air temperature was also included for comparison. Statistical analyses of the ambient temperatures in the MPBSs are given in Table 4. The black MPBS maintained higher $(P<$ $0.05)$ max ambient temperatures as compared with the white MPBS in the summer and fall (Table 4 and Fig. 5A and B). In the summer, from the beginning of the season until 2 July, the ambient temperature in the black MPBS showed an almost identical trend as the max air temperature. After 2 July, it maintained temperatures 0.5 to $3.5^{\circ} \mathrm{C}$ lower than the air temperature for the rest of the season. Similar results were obtained in the fall. The seasonal average ambient temperatures in the white MPBS were 1.8 and $1.7^{\circ} \mathrm{C}$ lower than those in the black MPBS in the summer and fall, respectively.

Water temperature patterns. Higher RZTs in the black MPBS during periods of extremely high air temperature may also be due to the temperature of the excess irrigation and rain water stored in the reservoir of the MPBSs. Figure $6 \mathrm{~A}$ and $\mathrm{B}$ shows the pattern of the water temperature in the reservoir of the black and white MPBSs in the summer and fall, respectively. Statistical analyses of the water temperatures in the MPBSs are given in Table 4. In both seasons, water temperature in the black MPBS was higher $(P<0.05)$ than the temperature in the white MPBS (Table 4). The minimum water temperatures were the same in both seasons. In the summer, the max water temperature in the black MPBS was up to 5.5 ${ }^{\circ} \mathrm{C}$ warmer than those in the white MPBS. The seasonal average water temperature in the black box was $2.3^{\circ} \mathrm{C}$ higher than the white MPBS. In the fall, the water temperature fluctuated much more than in the summer and the max water temperature was as much as $3.8^{\circ} \mathrm{C}$ higher in the black MPBS than the white. The seasonal average water temperature in the black MPBS was $1.8^{\circ} \mathrm{C}$ higher than the white MPBS.

The effect of irrigation water temperature on the substrate or plant root zone temperature depends on the temperature of both water and 

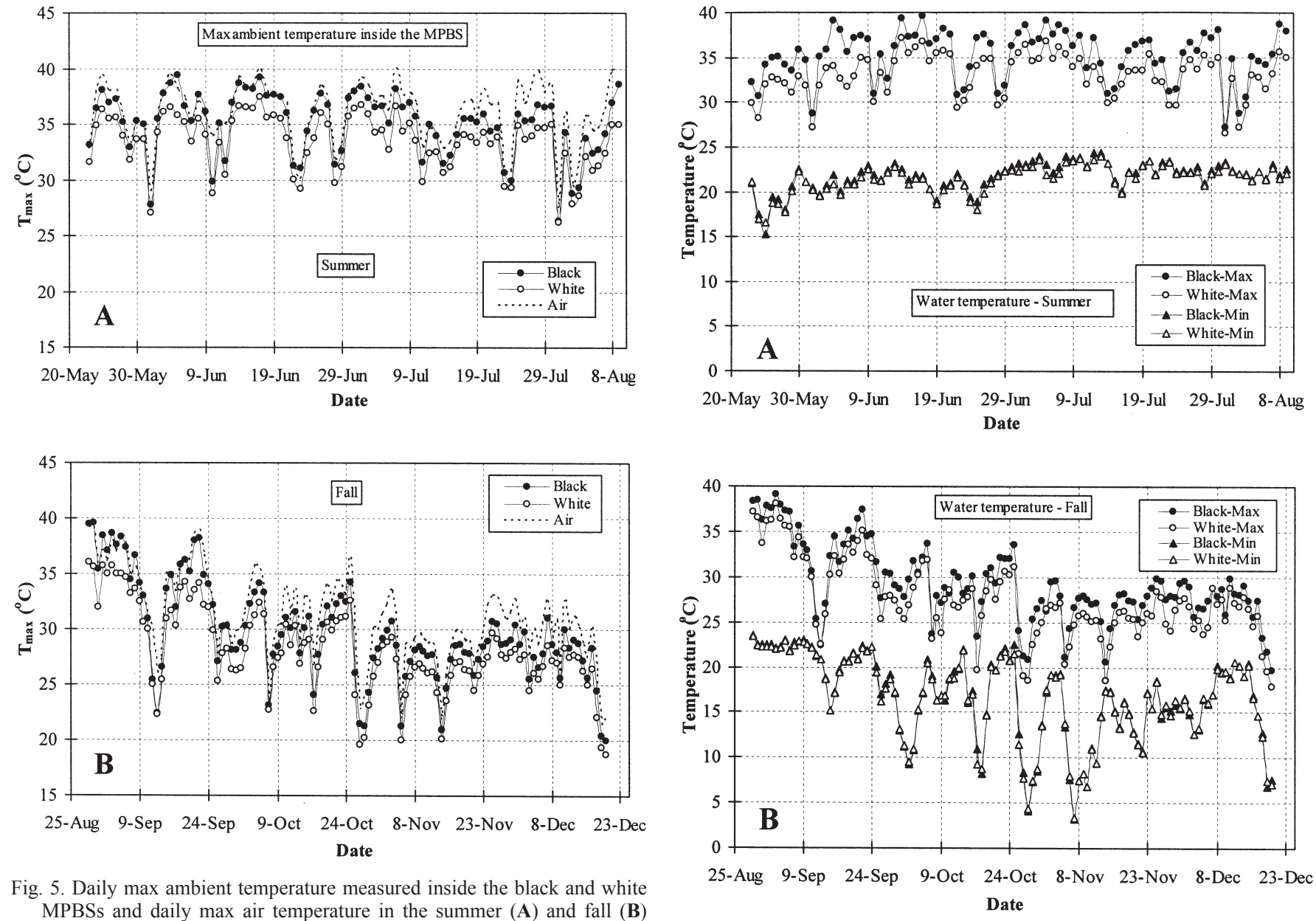

Fig. 5. Daily max ambient temperature measured inside the black and white MPBSs and daily max air temperature in the summer (A) and fall (B) seasons.

Fig. 6. Daily max and min water temperature in the white and black MPBSs in the summer (A) and fall (B) seasons.

Table 4. Statistical analysis of the max ambient temperatures $\left(\mathrm{T}_{\max }\right)$ measured in the black and white multipot box systems (MPBSs) and water temperatures measured in the reservoir of the MPBSs in the summer and fall growing seasons.

\begin{tabular}{lcrcc}
\hline $\begin{array}{l}\text { Growing } \\
\text { season } \\
\text { and variables }\end{array}$ & $\begin{array}{c}\text { Mean } \\
\text { square }\end{array}$ & \multicolumn{1}{c}{ F } & $\begin{array}{c}\text { F } \\
\text { critical }\end{array}$ & $P$ \\
\hline Summer-T $_{\text {max }}$ in the MPBSs (black vs. white) & 107.92 & 14.987 & 3.902 & $0.00016^{*}$ \\
Fall-T $_{\max }$ in the MPBSs (black vs. white) & 163.07 & 9.659 & 3.882 & $0.00213^{*}$ \\
Summer-T $_{\max }$ water (black vs. white) & 202.18 & 30.404 & 3.902 & $1.4 \mathrm{E}^{-7^{*}}$ \\
Fall-T $_{\max }$ water (black vs. white) & 183.94 & 10.107 & 3.882 & $0.00168^{*}$ \\
\hline
\end{tabular}

"Significant at 5\% significance level as indicated by Duncan's multiple range test (DMRT).

root zone and the heat capacity of the substrate used in the containers. In addition, water has a much higher specific heat than the substrate materials, and heat conductance through the substrate varies directly with substrate moisture content. During a sunny summer day, the temperature of the water may well exceed the RZT. For example, analysis indicated that the water temperature in the black MPBS was as much as $2.2^{\circ} \mathrm{C}$ higher than the RZT in the center of the container during the summer. During that season, the average water temperature was higher than the RZT for 44 out of $79 \mathrm{~d}$ (total growing season). Thus, since plants in the black MPBS uptake water from the reservoir, the irrigation water which is warmer than the plant root zone will cause an increase in root zone temperature due to the heat transfer into the root zone.

Minimum RZT profiles in the summer and fall. Seasonal patterns of RZT in the black and white MPBS and CS for the summer are given in Fig. 7A, B, and C, respectively. The $\mathrm{RZT}_{\min }$ in the same treatment were statistically the same for all depths $(P>0.05)$. Thus, temperature data from all depths in each treatment were averaged and analyzed. The averaged $\mathrm{RZT}_{\text {min }}$ were not significantly different between treatments for the summer or fall.

Daily patterns of RZT $_{\min }$ in the fall for the black and white MPBS and CS are presented in Fig. 8A, B, and C, respectively. Fall patterns were similar to those in the summer with lower $\mathrm{RZT}_{\min }$ in all treatments. In all treatments, daily RZT $_{\text {min }}$ fluctuated more in fall than the summer. The $\mathrm{RZT}_{\text {min }}$ were not significantly different between the treatments (Table 2). The RZT $\mathrm{T}_{\text {min }}$ showed almost identical patterns for all depths and there were no significant differences $(\mathrm{P}$ $>0.05)$ between depths for each treatment.
However, on days that the lowest and highest values of $\mathrm{RZT}_{\text {min }}$ occurred, there were noticeable differences between the treatments. For example, the lowest RZT min $_{\text {in }}$ the black MPBS was $2.4{ }^{\circ} \mathrm{C}$ on 7 Nov., while the lowest value in the white MPBS of $1.9^{\circ} \mathrm{C}$ occurred on the same day but was $0.5^{\circ} \mathrm{C}$ lower than the black MPBS. However, in the CS, RZT min $_{\text {m }}$ on Nov. was very close to freezing temperature $(0.2$ ${ }^{\circ} \mathrm{C}$ ) and was $2.2{ }^{\circ} \mathrm{C}$ and $1.7^{\circ} \mathrm{C}$ lower than the temperature in the black and white MPBSs, respectively.

Diurnal patterns of RZT. Diurnal patterns of the RZTs for different treatments can provide important information on the buffering capability of the black and white MPBS as compared to the CS containers. For this reason, four extreme days (warmest and coldest), two hottest days in summer and two coldest days in fall, were graphed to evaluate the diurnal RZT patterns. Since the patterns were similar for each hot and cold day, the pattern of one of the warmest and coldest days is discussed.

Warmest day pattern. On 17 June and 7 July, $2 \mathrm{~d}$ when the ambient max air temperature reached 40.0 and $40.1{ }^{\circ} \mathrm{C}$, respectively, were selected for analysis of summer. Diurnal patterns of max temperatures on 17 June and 7 July are presented in Fig. 9A and B for the black and white MPBSs, and CS at $0.12 \mathrm{~m}$. The RZT in the black and white MPBSs had identical values from 1 AM to 7 AM maintaining 
about $2.3{ }^{\circ} \mathrm{C}$ higher temperatures than the air temperature (Fig. 9). The RZT in the CS had identical values to the air temperatures in this period. On 17 June, the air temperature started increasing at $8 \mathrm{AM}$ whereas the temperature in the CS and MPBSs started rising at $10 \mathrm{AM}$, a 2-h delay. The rate of temperature rise in the white MPBS was the slowest. The RZT in the CS containers reached a max value of $46.8^{\circ} \mathrm{C}$ at $5 \mathrm{PM}$. The RZT in the black MPBS reached a maximum value of $40.8^{\circ} \mathrm{C}$ at $6 \mathrm{PM}$ and the white MPBS had the highest temperature as $38.1^{\circ} \mathrm{C}$ at the same time. The RZT in the white MBPS was $2.7^{\circ} \mathrm{C}$ cooler than the black MPBS and $6.9^{\circ} \mathrm{C}$ cooler than the $\mathrm{CS}$ at $6 \mathrm{PM}$. The maximum ambient temperature $\left(40.0^{\circ} \mathrm{C}\right)$ occurred at 2 PM. Both MPBSs responded similarly to the maximum ambient temperature with 4-h phase delays. The ambient temperature started decreasing rapidly at $3 \mathrm{PM}$. RZT $\mathrm{max}_{\max }$ in the white
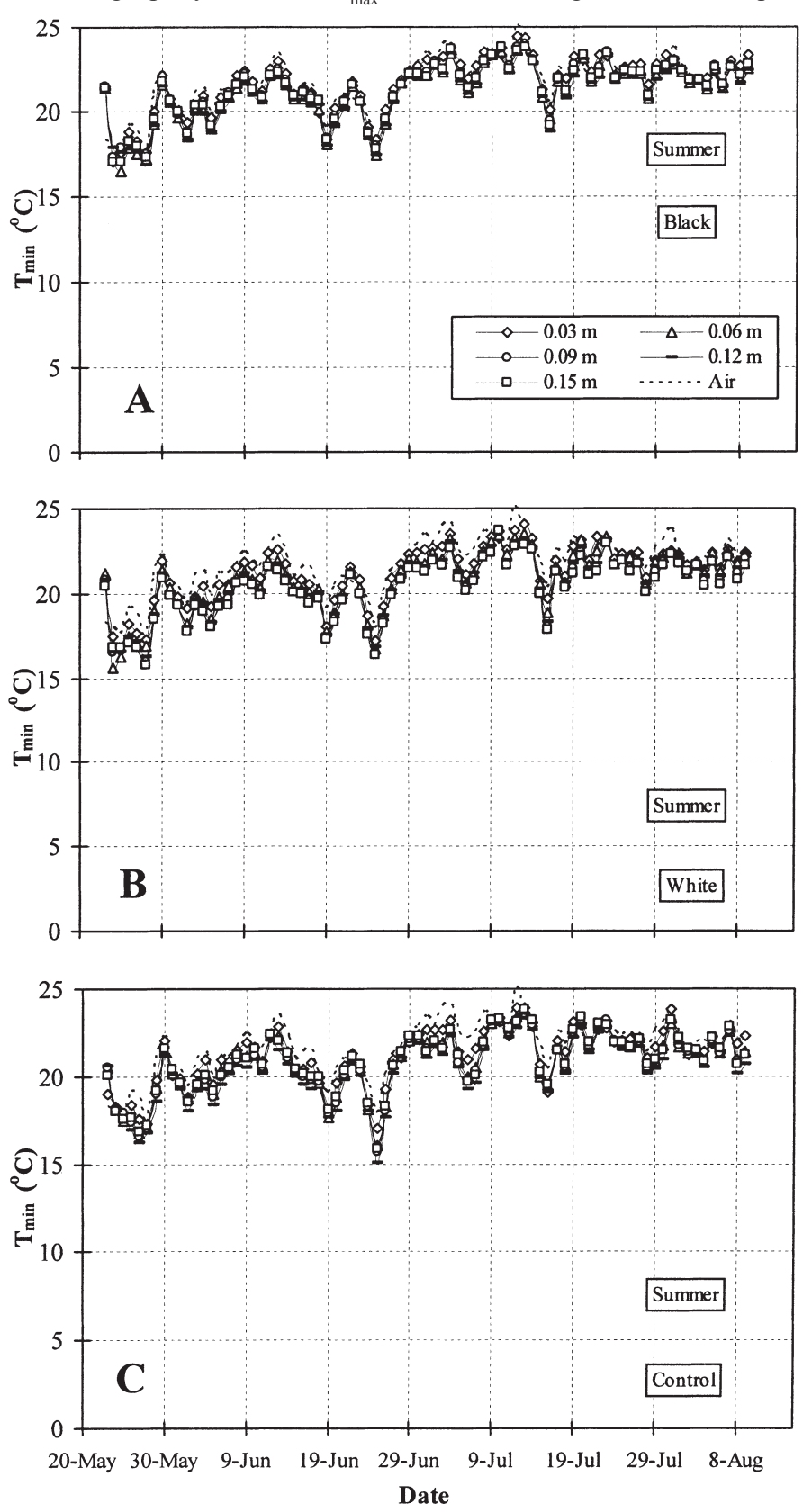

Fig. 7. Seasonal pattern of daily minimum RZT in the black (A) and white (B) MPBS, and CS (C) during the summer season. and plant growth. and black MPBSs started to decrease slowly at the same time at 7 PM with the RZT in the white MPBS cooling at a slower rate than the black MPBS and CS. The white MPBS maintained temperatures 0.7 to $2.3{ }^{\circ} \mathrm{C}$ cooler than the black MPBS and 1.6 to $6.9^{\circ} \mathrm{C}$ cooler than the CS treatment until 9 PM. Thus, the white MPBS successfully buffered the high ambient temperature and the system was more effective than the black MPBS and the CS in providing a desirable environment for root development

Coldest day pattern. Although the coldest ambient air temperature $\left(1.9^{\circ} \mathrm{C}\right)$ was recorded on 7 Nov. (Fig. 8C), the hourly temperature data for this day was not available. Therefore, two cold days, 28 Oct. and 19 Dec., when the min ambient air temperature dropped to 5.1 and 6.0 ${ }^{\circ} \mathrm{C}$, respectively, were selected and graphed in Fig. 10A and B, respectively. Only the diurnal pattern of RZTs on 28 Oct. will be discussed in detail.
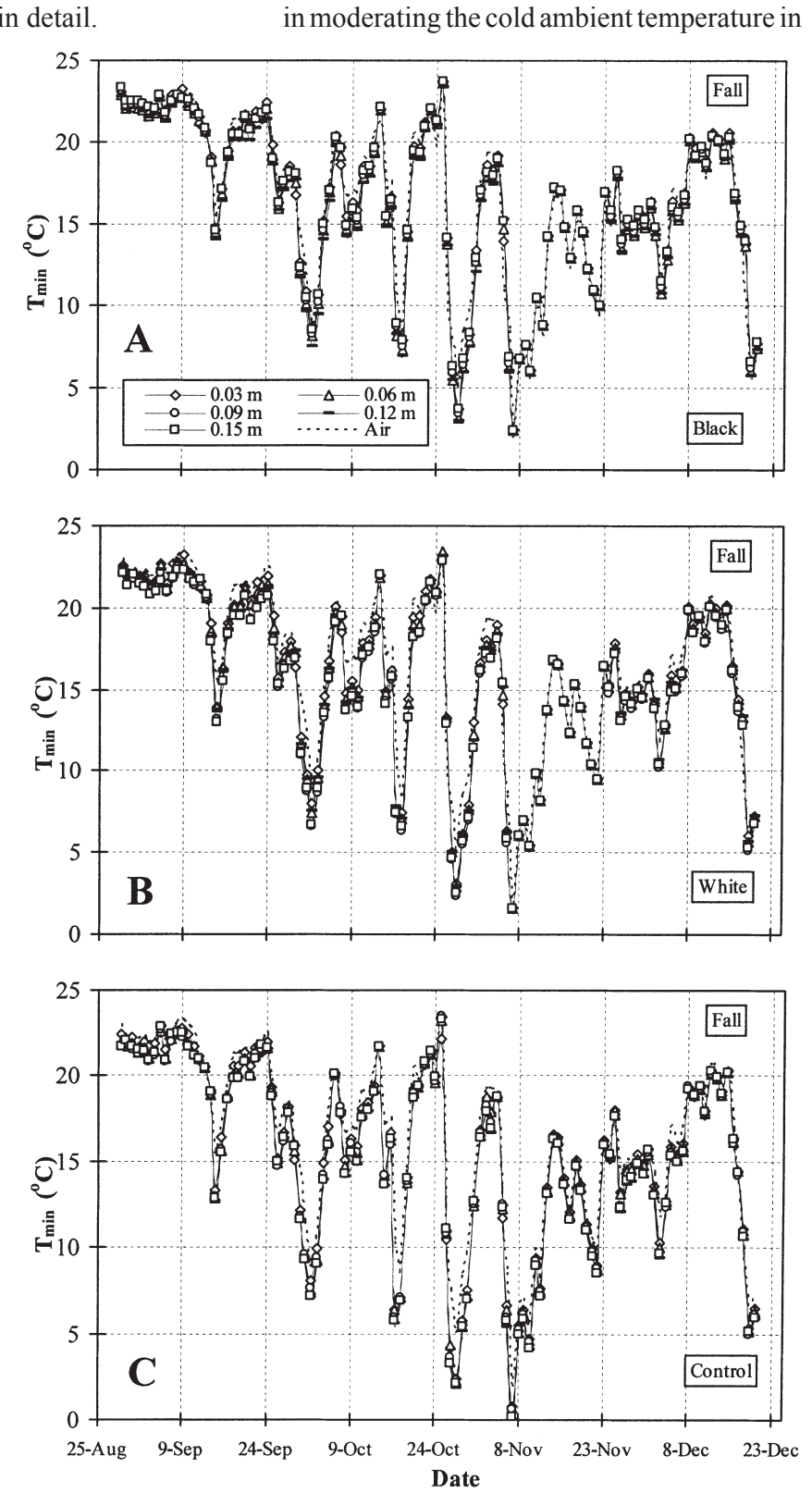

Fig. 8. Seasonal pattern of daily minimum RZT in the black (A) and white (B) MPBS, and CS (C) during the fall season. 

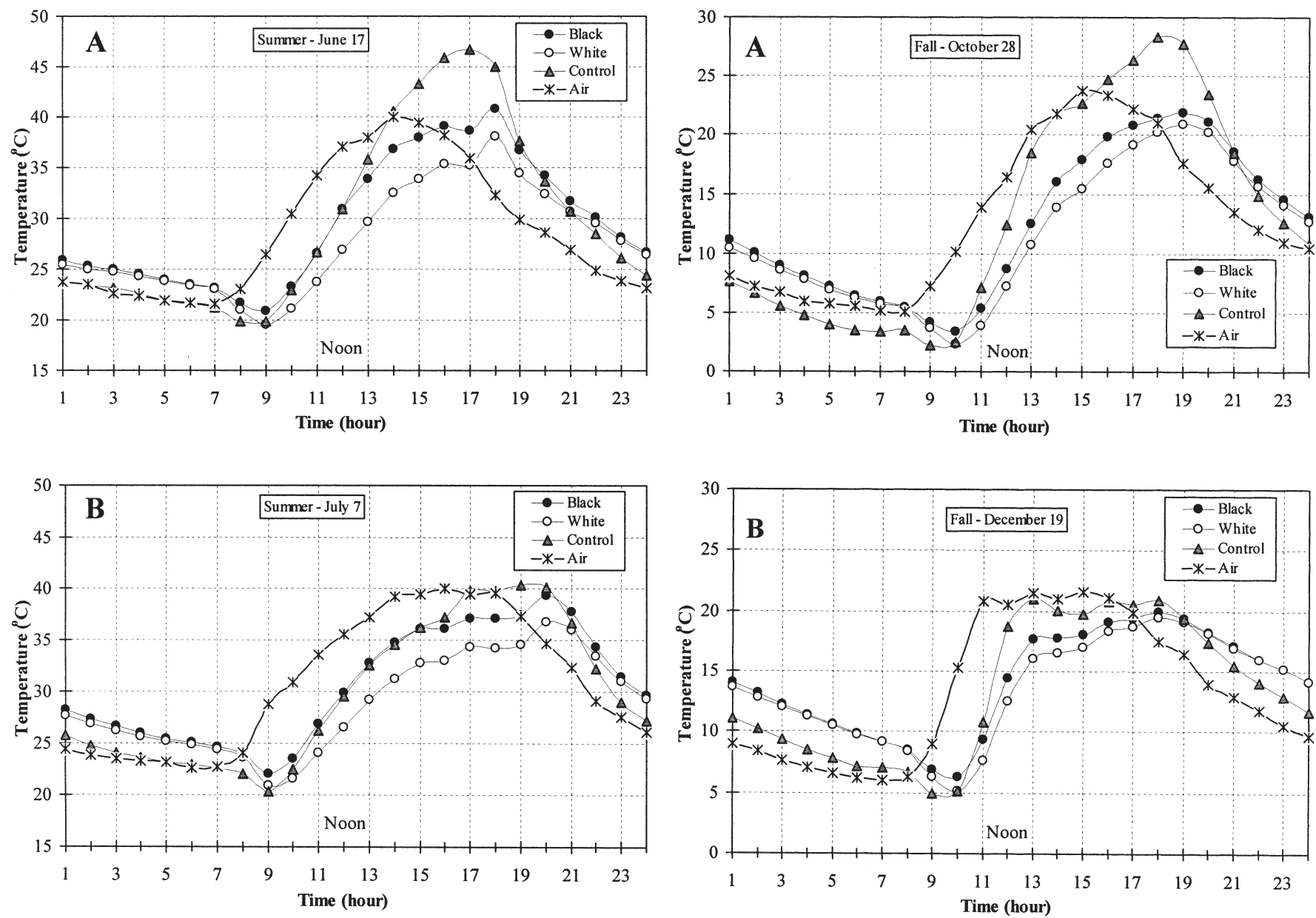

Fig. 9. Diurnal RZTs (warmest days pattern in the summer season) of the black and white MPBSs and CS on 17 June (A) and 7 July (B) when ambient air temperature reached 40.0 and 40.1 ${ }^{\circ} \mathrm{C}$, respectively.

the plant root zone as compared to the white MPBS and CS. After $10 \mathrm{AM}$, the RZTs in the CS increased rapidly to $7.1^{\circ} \mathrm{C}$ at $11 \mathrm{AM}$ whereas the temperature in the black and white MPBSs increased at a much slower rate reaching 5.4 and $3.9^{\circ} \mathrm{C}$, respectively. Similar trends of diurnal patterns of the RZTs in all treatments were observed on 19 Dec. (Fig. 10B).

Overall results showed that the white MPBS successfully moderated RZTs against extremely high ambient temperatures during the warm periods in the summer and fall. However, the black MPBS was more effective in moderating the cold temperature on the cold days in the fall. On 28 Oct., the lowest temperature in the black MPBS was $0.8^{\circ} \mathrm{C}$ higher than the RZT in the white MPBS. Similar results were obtained on the other cold day of the season (19 Dec.). On this day, the RZT in the black MPBS was $1.1^{\circ} \mathrm{C}$ warmer than the RZT in the white MPBS (Fig. 10B). These results suggest that in cold climates, the black MPBS might have an advantage over white MPBS in protecting the root zone against cold ambient air temperatures. The RZT moderation with the black and white MPBSs under colder climates needs to be further researched.

\section{Results of RZT predictions}

RZT models for the white and black MPBS. Data analyses showed that the maximum temperatures measured in five depths $(0.03,0.06$, $0.09,0.12$, and $0.15 \mathrm{~m}$ from the surface of the container) in the substrate of the black or white
Fig. 10. Diurnal RZTs (coldest days pattern in the fall season) of the black and white MPBSs and CS on 28 Oct. (A) and 19 Dec. (B) when ambient air temperature dropped to 5.1 and $6.0^{\circ} \mathrm{C}$, respectively.

MPBSs were not different between depths. However, when temperatures in five depths were averaged for the season, the black MPBS was warmer $(P<0.05)$ than the white MPBS in two seasons. The min temperatures were not different between the depths or between the black or white MPBSs in both seasons. Therefore, two models were developed to predict the $\mathrm{RZT}_{\max }$ at the $0.12 \mathrm{~m}$ depth for the white and black MPBS. Only one model was developed to predict $\mathrm{RZT}_{\text {min }}$ at the same depth. Results reported earlier in the paper indicated that there were differences in RZT between the depths for the CS. However, $\mathrm{RZT}_{\min }$ between

Table 5. Root mean square error (RMSE), seasonal average ratio of predicted root zone temperatures (RZTs) to measured RZT, $r^{2}$, and significance of the independent variables for equations developed. RZT was calculated on a daily basis and then averaged to obtain seasonal average.

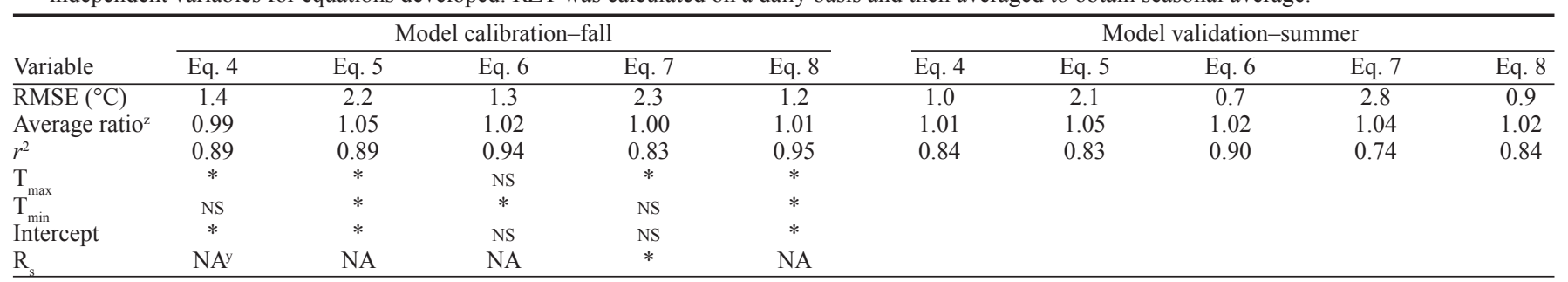

${ }^{2}$ Daily ratios of predicted RZT to measured.

${ }^{\mathrm{N}} \mathrm{NA}=$ not applicable.

NS," Significant at $5 \%$ significance level as indicated by Duncan's multiple range test. 
the depths were the same $(P>0.05)$, while the max and RZT $_{\text {min }}$ were different than the RZTs in the white and black MPBSs. Thus, for the CS, two models were developed to predict $\mathrm{RZT}_{\text {max }}$ and $\mathrm{RZT}_{\text {min }}$ at the $0.12 \mathrm{~m}$ depth from the surface.

Fall was selected for model calibration because the temperature range was larger ranging from 1.9 to $40{ }^{\circ} \mathrm{C}$ as compared to the summer $\left(17.4\right.$ to $\left.40^{\circ} \mathrm{C}\right)$. Calibration equations for predicting $\mathrm{RZT}_{\max }\left({ }^{\circ} \mathrm{C}\right)$ for the substrate at the $0.12 \mathrm{~m}$ from the surface in the white and black MPBS, respectively, were found as $\mathrm{RZT}_{\text {max-white }}=1.184 \mathrm{~T}_{\max }-0.058 \mathrm{~T}_{\min }-2.938$ [4] $\mathrm{RZT}_{\text {max-black }}^{\text {max-white }}=1.272 \mathrm{~T}_{\text {max }}-0.011 \mathrm{~T}_{\text {min }}-3.467$ [5] and the equation for predicting $\operatorname{RZT}_{\text {min }}\left({ }^{\circ} \mathrm{C}\right)$ in either black or white MPBS was found as $\mathrm{RZT}_{\min }=0.082 \mathrm{~T}_{\max }+0.953 \mathrm{~T}_{\text {min }}-1.501 \quad$ [6]

Calibration parameters and the RMSE between the predicted and observed RZTs, the seasonal average of predicted RZTs to measured RZTs, and the significance of the independent variables for the calibration season are presented in Table 5.

Data analyses indicated that incoming solar radiation, $\mathrm{R}$, did not have a significant effect on RZT $_{\text {max }}$ in the MPBSs, thus, it was excluded from Eqs. 4 and 5. This is related to the fact that the MPBS containers were protected from direct exposure to the solar radiation with the exception of the container surface in the early growing season due to the reduced canopy cover. In Eq. 4 , the $r^{2}$ value was 0.89 for the calibration. The intercept and $\mathrm{T}_{\max }$ of the regression line were significant ( $P$ $<0.05, \mathrm{n}=114)($ Table 5) with the RMSE averaging $1.4^{\circ} \mathrm{C}$. In Eq. 5, the $r^{2}$ was same as Eq. 4 (0.89). The intercept, $\mathrm{T}_{\text {max }}$, and $\mathrm{T}_{\min }$ were significant with the RMSE averaging with a higher value $\left(2.2^{\circ} \mathrm{C}\right)$ compared to the Eq. 4 . In the calibration equation of $\mathrm{T}_{\min }$ (Eq. 6), only the $T_{\text {min }}$ was significant and the RMSE was 1.3 ${ }^{\circ} \mathrm{C}$. The seasonal average ratio of predicted RZTs to measured values was $0.99,1.05$, and 1.02 for Eqs. 4, 5, and 6, respectively, with Eq. 5 overestimating $\mathrm{T}_{\max }$ for the black MPBS. Although $\mathrm{T}_{\min }$ in Eq. 4 and $\mathrm{T}_{\max }$ in Eq. 6 were not significant, they were included in the calibration equations because their inclusion increased the $r^{2}$ value from 0.92 to 0.94 and decreased the RMSE of the predictions from 1.6 to $1.3{ }^{\circ} \mathrm{C}$. In the calibration of Eq. 6 , the discrepancies between the measured and predicted RZTs were the largest in the measured temperature range between about 10 and 20 ${ }^{\circ} \mathrm{C}$. This might be due to the larger fluctuations in daily RZT ${ }_{\text {min }}$ toward the end of the fall. The largest fluctuations in daily $\mathrm{RZT}_{\text {min }}$ occurred in the November to December period when the temperature differences between the daytime and nighttime RZT ${ }_{\min }$ were the greatest.

The results of the RZT predictions for the validation season (Eqs. 4, 5, and 6 versus measured RZTs in the summer), RMSE, and the seasonal average ratio of predicted RZTs to measured RZTs are presented in Table 5 . Predicted RZTs using Eq. 4 were well correlated with the measured RZT . Equation 4 resulted in a reasonably low RMSE (1.0 ${ }^{\circ} \mathrm{C}$ ) with an $r^{2}$ value of 0.84 and the seasonal average ratio of 1.01 (Table 5).
The results ofEq. 5 were slightly poorer than Eq. 4. Note that the calibration results of Eq. 5 in Table 5 showed that the Eq. 6 overpredicted $\mathrm{RZT}_{\max }$ in the black MPBS with a seasonal average ratio of 1.05 . This overestimation was consistent throughout the season. The overestimation of the Eq. 5 is related to the considerable differences in temperature range between the calibration and validation seasons. For example, in the calibration season (fall), RZT $_{\max }$ of the substrate at $0.12 \mathrm{~m}$ in the black MPBS ranged from 19.8 to $40.6{ }^{\circ} \mathrm{C}$ whereas it ranged from 27.6 to $40.0^{\circ} \mathrm{C}$ in the summer. However, the magnitude of overprediction is within the acceptable range. Predicted RZTs were well correlated with the measured RZTs with an $r^{2}$ of 0.83 while the average ratio was 1.05 , and the RMSE was $2.1^{\circ} \mathrm{C}$.

Equation 6 predicted RZT ${ }_{\text {min }}$ very successfully for the black and white MPBSs. The RMSE of predictions was the lowest $\left(0.7^{\circ} \mathrm{C}\right)$ and the $r^{2}$ was the highest (0.90) among all equations. The average ratio of 1.02 indicates that the equation slightly overpredicted RZT The overpredictions were larger at lower RZ $\mathrm{T}_{\text {min }}$ (from 17 to $20^{\circ} \mathrm{C}$ ). This is because in the model calibration and validation, the average of five depth's RZT max $_{\text {and }}$ RZT min $_{\text {mere used }}$ and, thus, using average RZT values from all depths might have introduced some bias to the model performance in the validation season. Also, Eqs. 4, 5, and 6 only use $\mathrm{T}_{\max }$ and $\mathrm{T}_{\min }$ to predict RZTs. They do not account for other environmental variables such as evaporation, conduction, water content and thermal properties of the substrate, and other variables that might influence the RZT. The main objective of this study was to develop simple but practical and accurate models that can be used to predict RZTs using commonly available climate variables. The model performances showed that Eqs. 4, 5, and 6 were effective and can be used to predict $\mathrm{RZT}_{\max }$ and $\mathrm{RZT}_{\text {min }}$ with sufficient accuracy for Viburnum odoratissimum grown in the black and white MPBSs.

RZT models for CS. The calibration equations for predicting $\mathrm{RZT}_{\text {max }}$ and $\mathrm{RZT}_{\text {min }}$, respectively, for the substrate at a depth of 0.12 $\mathrm{m}$ in the CS containers were

$\mathrm{RZT}_{\max }=0.850 \mathrm{~T}_{\max }+0.026 \mathrm{~T}_{\min }+0.697 \mathrm{R}_{\mathrm{s}}+1.21[7]$

$\mathrm{RTZ}_{\text {min }}=0.106 \mathrm{~T}_{\text {max }}+0.998 \mathrm{~T}_{\text {min }}-3.255$

where $R_{s}$ is the daily average incoming solar radiation $\left(\mathrm{MJ} \cdot \mathrm{m}^{-2} \cdot \mathrm{d}^{-1}\right)$. Using only $\mathrm{T}_{\text {max }}$ and $\mathrm{T}_{\text {min }}$ in the model of RZT max for the CS resulted in poor predictions with low $r^{2}$ and high RMSE of 0.64 and $4.0^{\circ} \mathrm{C}$, respectively. Therefore, $\mathrm{R}_{\mathrm{s}}$ was included in the calibration. The calibration parameters for Eqs. 7 and 8 are given in Table 5.

In the calibration of Eq. 7, the $r^{2}$ value was 0.83 and only $\mathrm{T}_{\text {max }}$ and $\mathrm{R}_{\mathrm{s}}$ were significant $(P<$ $0.05, \mathrm{n}=79$ ) with the RMSE of $2.3{ }^{\circ} \mathrm{C}$ (Table 5). In Eq. 8, the $r^{2}$ was the highest (0.95) and the RMSE was the lowest $\left(1.2^{\circ} \mathrm{C}\right)$ among all calibration equations. In Eq. $8, \mathrm{R}_{\mathrm{s}}$ was not included since it did not have a significant contribution in predicting $\mathrm{RTZ}_{\min }$. All other variables were significant. The seasonal average ratios of predicted RZT to measured values for Eqs. 7 and 8, respectively, were 1.00 and 1.01 indicating that the model predictions did not deviate from the measured values. Martin and Ingram (1992) stated that the primary environmental factors causing changes in substrate temperature patterns are solar radiation, wind speed, air temperature, and absolute air humidity. The analyses in our study during model development indicated that the wind speed and humidity did not have significant contribution on predicting $\mathrm{RTZ}_{\max }$ in the MPBSs or CS at the $0.12 \mathrm{~m}$ depth. However, these variables would most likely influence substrate temperature at the top depth $(0.03 \mathrm{~m}$ from the surface) because this depth is in a direct contact with the surrounding environment. The influence of above-mentioned variables on the RZT would most likely depend on plant growth and plant canopy development due to the shading effects on the RZTs.

Predicted RZTs using Eq. 7 were correlated well with the measured $\mathrm{RTZ}_{\max }$ in the CS. The Eq. 7 predictions resulted in the highest RMSE $\left(2.8^{\circ} \mathrm{C}\right)$ and the lowest $r^{2}(0.74)$ among all other equations and the seasonal average ratio was 1.04 (Table 5) overpredicting RZT. Equation 8 was very successful for predicting $\mathrm{RTZ}_{\text {min }}$ in the CS. The RMSE of predictions was the second lowest $\left(0.9^{\circ} \mathrm{C}\right)$ among all the equations with the $r^{2}$ and average ratio of 0.84 and 1.02 , respectively.

Overall results indicated that Eqs. 4 through 8 can successfully predict $\mathrm{RTZ}_{\max }$ and $\mathrm{RTZ}_{\min }$ in the white and black MPBSs and the CS at the $0.12 \mathrm{~m}$ depth. Models were able to explain at least $74 \%$ of the variability in RZTs using only $\mathrm{T}_{\max }, \mathrm{T}_{\text {min }}$, and/or $\mathrm{R}_{\mathrm{s}}$, depending on the equation. In the validation season, the accuracy of the RZT predictions of all equations was slightly poorer than those in the calibration season. This is expected since there are some experimental and management practices, such as thermocouple placement depths, compaction of the substrate in the container, plant orientation, canopy cover, etc., that might be different in the validation season than the calibration season. Although it would be ideal to develop a model that can be used under a variety of management and cultural conditions. In practice, this would be very difficult to accomplish because horticultural and nursery industry produces hundreds of different plant species grown in many different substrate combinations under many different management, cultural, and climatic conditions. Thus, it was not the intent of this study to develop models that can be used in every condition. In addition, in some cases root injury can also occur at the periphery of the container. The models of this study were developed to predict the RZT at the center of the container about $0.05 \mathrm{~m}$ from the bottom of the container and do not predict the RZT at the periphery of the container. However, the models provide crucial information and data on the RZT profiles for container-grown ornamental plants.

\section{Summary and Conclusions}

This study compared RZTs for containergrown $V$. odoratissimum grown in black and white MPBSs, and a conventional system (CS) in Summer and Fall 2001 in north-central 
Florida. The overhead sprinkler-irrigated CS served as the control treatment and represented the irrigation system used by the majority of the nursery growers. The MPBS treatments were irrigated with drip irrigation. The system reservoir allowed the capture of rain and excess irrigation water for later use by plants via subirrigation. Thus, water in the substrate was replaced by capillary mats as needed. The study also deals with the development, calibration, and validation of a series of models that can be used to predict $\mathrm{RTZ}_{\text {max }}$ and $\mathrm{RTZ}_{\text {min }}$ using commonly available input variables. RZTs were measured at five depths $(0.03,0.06,0.09,0.12$, and $0.15 \mathrm{~m}$ from the container surface). During the model development, the critical plant root zone is assumed to be about $1 / 3$ of the distance from the bottom of the container $(0.12 \mathrm{~m}$ from the container surface). Models were developed using the RZT as the dependent variable and $\mathrm{T}_{\text {min }}, \mathrm{T}_{\max }$, and/or $\mathrm{R}_{\mathrm{s}}$ as independent variables. Black MPBS maintained higher max ambient temperature compared to the white MPBS in both seasons. The RZTs in the black MPBS and $\mathrm{CS}$ exceeded the critical value $\left(40^{\circ} \mathrm{C}\right)$ for a few hours during the summer. The $40^{\circ} \mathrm{C}$ value is cited in the literatures as negatively impacting root growth, leaf area, plant survival, root and shoot dry weights, and photosynthesis when plants are exposed to this extreme temperature for the duration of 5 to $6 \mathrm{~h} \cdot \mathrm{d}^{-1}$. RZT in the CS was above $45^{\circ} \mathrm{C}$ for most of the summer. The MPBS successfully insulated plant root zone against extremely high ambient temperatures in all depths during both seasons and provided a more optimal environment which enhanced plant growth. Models based on $\mathrm{T}_{\text {max }}$ and $\mathrm{T}_{\text {min }}$ were able to explain $84 \%$ and $83 \%$ of the variability in $\mathrm{RTZ}_{\text {max }}$ of substrate in the white and black MPBSs, respectively. Using $\mathrm{T}_{\max }, \mathrm{T}_{\text {min }}$, and/or $\mathrm{R}_{\mathrm{s}}$ in the model for the CS allowed predicting at least $74 \%$ of the variability in $\mathrm{RTZ}_{\text {max }}$. RTZ min $_{\text {min }}$ predictions for MPBSs and CS were better than for RTZ provide adequate and effective RZT protection for $V$. odoratissimum grown in no. 1, 3.8-L standard black conventional containers without insulation for regions where ambient air temperature range from 2 to $41^{\circ} \mathrm{C}$. Models developed in this study can be used to accurately predict daily $\mathrm{RTZ}_{\text {max }}$ and $\mathrm{RTZ}_{\text {min }}$ of the substrate in the locations where ambient air temperature ranges from 1.9 to $40{ }^{\circ} \mathrm{C}$ under climatic, management, and cultural practices similar to those found in this study.

\section{Literature Cited}

Florida Dept. of Agriculture and Consumer Services. 1997. Grades and standards for nursery plants. Fla. Dept. Agr. Consumer Serv., Gainesville.

Fretz, T.A. 1971. Influence of physical conditions on summer temperatures in nursery containers. HortScience 6:400-401.

Graves, W.R., M.N. Dana, and R.J. Joley. 1989. Root zone temperature affects water status and growth of red maple. J. Amer. Soc. Hort. Sci. 114:406-410.

Haman, D.Z., T.H. Yeager, R.C. Beeson, Jr., and G.W. Knox. 1998. Multiple pot box for container plant production. J. Environ. Hort. 16(1):60-63.

Ingram, D.L. 1981. Characterization of temperature fluctuations and woody plant growth in white poly bags and conventional black containers. HortScience 16:762-763.

Ingram, D.L., C. Ramcharan, and T. Nell. 1986. Response of container-grown banana, ixora, citrus, and dracaena to elevated root temperatures. HortScience 21:254-255.

Ingram, D.L. and C. Ramcharan. 1988. 'Grande Naine' banana and Dracaena marginata 'Tricolor' root cell membrane heat tolerance. Fruits 43:29-33.

Ingram, D.L., C.A. Martin, and J.M. Ruter. 1989. Heat-stress of container-grown plants. Intl. Plant Prop. Soc. Proc. 39:348-353.

Irmak, S., D.Z. Haman, T.H. Yeager, and C. Larsen. 2001. Seasonal irrigation water use efficiency of multi-pot box system. J. Environ. Hort. 19(1):4-10.

Irmak, S. 2002. A new irrigation-plant production system for water conservation in ornamental nurseries. PhD diss. Univ. Fla., Gainesville.

Irmak, S., D.Z. Haman, A. Irmak, J.W. Jones, T.H. Yeager, and K.L. Campbell. 2003. A new irrigation-plant production system for water conservation in ornamental nurseries: Quantification and evaluation of irrigation, runoff, plant biomass, and irrigation efficiencies. Appl. Eng. Agr. 19(6):651-655.

Irmak, S., D.Z. Haman, A. Irmak, K.L. Campbell, J.W. Jones, and T.L. Crisman. 2004. Measurement and analyses of growth and stress parameters of Viburnum odoratissimum (Ker-gawl) grown in a MPBS. J. Amer. Soc. Hort Sci. 39(6):1445-1455.

Johnson, C.R. and D.L. Ingram. 1984. Pittosporum tobira response to container medium temperature. HortSci. 19:524-525.

Levitt, J. 1980. Responses of plant to environmental stresses. vol. 1. Chilling, freezing, and high temperatures stresses. Academic Press, New York, N.Y.

London, J., G.D. Christenbury, R.T. Fernandez, and R.E. Young. 1998. Media temperatures and plant growth in above-ground and in-ground pot-in-pot container systems. Amer. Soc. Agr. Eng. Paper No. 98-7008.
Martin, C.A. and D.L. Ingram. 1988. Temperature dynamics in poly containers. S. Nurseryman Res. Conf. 33:71-74.

Martin, C.A., D.L. Ingram, and T.A. Nell. 1989. Supraoptimal root zone temperatures alters growth and photosynthesis of holly and elm. J. Arboricult. 15:272-276.

Martin, C.A. 1990. Modeling temperature patterns in a container media and acclimatization of three tree species to supraoptimal root zone temperatures. PhD diss. Univ. Fla., Gainesville.

Martin, C.A., D.L. Ingram, and T.A. Nell. 1991. Growth and photosynthesis of southern magnolia in response to increased and constant container volume. J. Amer. Soc. Hort. Sci. 116:439-445.

Martin, C.A. and D.L. Ingram. 1992. Simulation modeling of temperatures in root container media. J. Amer. Soc. Hort. Sci. 117(4):571-577.

Martin, C.A. and D.L. Ingram. 1993. Container dimension affects rooting medium temperature patterns. HortScience 28(1):18-19.

Parkerson, C.H. 1990. P \& P: A new field-type nursery operation. Proc. Intl. Plant Prop. Soc. 40:417-419.

Ruter, J.M. and D.L. Ingram. 1990. 14Carbon-labeled photosynthate partitioning in Ilex crenata 'Rotundifolia' at supraoptimal root zone temperatures. J. Amer. Soc. Hort. Sci. 115:1008-1013.

Ruter, J.M. and D.L. Ingram. 1992. High root zone temperatures influence RuBisCo activity and pigment accumulation in leaves of 'Rotundifolia' holly. J. Amer. Soc. Hort. Sci. 117(1):154-157.

Ruter, J.M. 1993. Growth and landscape performance of three landscape plants produced in conventional and Pot-In-Pot production systems. J. Environ. Hort. 11(3):124-127.

Schluckebier, J.G. and C.A. Martin. 1997. Effect of above ground pot-in-pot (PIP) placement and humic acid extract on growth of crape myrtle. J. Environ. Hort. 15:41-44.

Yeager, T.H., R.H. Harrison, and D.L. Ingram. 1991. Rotundifolia holly growth and nitrogen accumulation influenced by supraoptimal root zone temperatures. HortScience 26(11):1387-1388.

Young, R.E., J.L. Dunlap, Jr., D.J. Smith, and S.A. Hale. 1987. Clear and white plastics for freeze protection of landscape plants in the southern to mid-atlantic region. J. Environ. Hort. 5:166-172.

Young, R.E. and G.R. Bachman. 1996. Temperature distribution in large, Pot-In-Pot nursery containers. J. Environ. Hort. 14(4):170-176.

Young, K. and K.R.W. Hammett. 1980. Temperature patterns in exposed black polyethylene plant containers. Agr. Meteorol. 21:165-172.

Wong, T.L., R.W. Harris, and R.E. Fissell. 1971. Influence of high soil temperatures on five woody-plant species. J. Amer. Soc. Hort. Sci. 96:80-82. 